\title{
JANINA ŠVAMBARYTĖ-VALUŽIENĖ
}

Lietuviuc kalbos institutas

Mokslinių tyrimų kryptys: rašytinių šaltinių tarmès analizè, tarmių leksikografija ir leksikologija, sociolingvistika, sintaksè.

D O I

FONETINĖS IR

MORFOLOGINĖS ŽAGARĖS ŠNEKTOS YPATYBĖS

(XX a. PABAIGA - XXI a. PRADŽIA)

\author{
Phonetic and Morphological Peculiarities \\ of Žagare Local Dialect (End of the 20 $0^{\text {th }}$ \\ Century - Beginning of the $21^{\text {st }}$ Century)
}

\begin{abstract}
ANOTACIJA
Autore tęsia vakarų aukštaičiams šiauliškiams priklausančių Joniškio šnektų tyrimą (aprašą). Straipsnyje aptariamos fonetinès ir morfologinès Žagarès šnektos, paskutinès iš aprašomųiu Joniškio šnektų, ypatybės, atspindėtos tarminiuose įrašuose, darytuose XX a. pabaigoje ir XXI a. pradžioje (nuo 1999 iki 2003 m.). Aprašomi pastebėti Žagarès šnektos fonetiniai ir morfologiniai reiškiniai, diskutuotini akcentuacijos polinkiai, pateikiamas žvalgomasis leksikos savitumo aprašas.

ESMINIAI ŽODŽIAI: vakarų aukštaičiai šiauliškiai, Žagarès šnekta, Žagarès šnektos fonetinės ypatybės, Žagarès šnektos morfologinè raiška ir leksikos savitumas.
\end{abstract}

\section{ANNOTATION}

The author continues the study (description) of Joniškis local dialects which belong to the Western Aukštaitian Subdialect of Šiauliškiai. The article discusses the phonetic and morphological peculiarities of Žagare local dialect, the last Joniškis local dialect under 
analysis, which are reflected in the dialectal records made at the end of the $20^{\text {th }}$ century and the beginning of the $21^{\text {st }}$ century (from 1999 to 2003). The article describes the identified phonetic and morphological phenomena in Žagare local dialect, the questionable tendencies of accentuation and provides a pilot description of lexical peculiarities.

KEYWORDS: Western Aukštaitian Subdialect of Šiauliškiai, Žagare local dialect, phonetic peculiarities of Žagarẻ local dialect, morphological expression and lexical peculiarities of Žagarè local dialect.

\section{IVADAS}

Autorè yra nustačiusi Žagarès šnektos ribas, bet kalbinių reiškinių nèra aptarusi ${ }^{1}$. Apie artimos Žagarès šnektai - Skaistgirio šnektos - fonetinius ir morfologinius reiškinius publikaciją yra paskelbusi kalbininkė Aušra Kaikarytè2. Pavienius fonetinius ir morfologinius Žagarès šnektos savitumus yra aptarę dialektologai Aldona Jonaitytė, Aleksas Girdenis, Genovaitė Kačiuškienė, Juozas Pabrėža ${ }^{3}$. Remiantis tarmètyrininkų darbuose išsakytomis mintimis ir autorès iž̌valgomis, pastebėtomis klausantis iૃrašų, siekiama pateikti kiek ne kiek apibendrintą Žagarès šnektos vaizdą ir numatyti tolimesnio tiriamojo darbo gaires.

Straipsnio medžiaga - Žagarès šnektos įrašai, saugomi Lietuvių kalbos instituto Tarmių archyve ${ }^{4}$. Tiriami tarminiai įrašai apima XX a. pabaigos ir XXI a. pradžios (1998-2003 m.) laikotarpi ${ }^{5}$. Apklausti vyriausiosios kartos respondentai, gimę nuo 1901 iki 1936 m. Irrašyta 16 kasečių tarminių ịrašų, sudarančių apie 1440 val. teksto. İrašai daryti nevienodą respondentų apklausos ir tarminès

1 Žr. ̌̌vambarytè $2018: \overline{135}-\overline{148 .}$

2 Žr. Kaikarytė 2015: 150-173.

${ }^{3}$ Autorè atsižvelgia į A. Kaikarytės ir kitų dialektologų darbuose išryškintus Žagarės šnektos savitumus; derinasi prie paskelbtų straipsnių struktūros apie Joniškio ir Skaistgirio šnektas; cituoja (o ne perpasakoja) tyrejjų mintis, kad būtų galima arba pagrịsti, arba išsakyti savo abejones dèl moksliniuose darbuose išsakytų teiginių. Autore specialiai nerinko pavyzdžių iš Žagarės šnektos tekstų teiginiams iliustruoti, o aptarè visus (ir nesisteminius) šnektos fonetinius, akcentuacinius, morfologinius raiškos atvejus.

${ }^{4}$ Tiriamoji medžiaga detaliau aprašyta autorès straipsnyje $2018 \mathrm{~m}$.

${ }^{5}$ LKI TA saugoma ir vèlesnių metų ịrašai, pavyzdžiui, daryti 2011-2013 m., bet jais straipsnio autorè nesiremia dèl vienos priežasties - respondentų amžiaus. Vyriausioji karta geriausiai atspindi tradicinę tarmę, o tokių respondentų tarminių įrašų daugiausia padaryta nurodytais metais. 
Fonetinės ir morfologinès Žagarès šnektos ypatybès

(XX a. pabaiga - XXI a. pradžia)

kalbos įrašymo patirtị turinčių moksleivių, studentų ir doktorantų ${ }^{6}$. Respondentų kalbamąsias temas galima būtų suskirstyti i penkias grupes:

a) Žagarès istorija ir jos interpretacija (legendos apie Žagarès vardo atsiradimą; apie žiemgalius ir jų kunigaikščius; apie Naryškino dvarą ir jo mišku prižiūrètojus (eigulius);

b) pramonė ir pramonès įmonių veikla (apie Žagarèje veikusias pieninę, sagų fabriką; apie vykusią prekybą ir prekybinį kelią i̇ Rygą; apie kontrabandą, klestejusią pasienyje; apie amatininkus, įsikūrusius Žagarèje ir pan.);

c) religija ir šventieji (apie įvairiu religinių konfesijų žmonių sugyvenimą; apie Senosios ir Naujosios Žagarės bažnyčias; apie Barborą Umiastauskaitę);

d) mokslas ir raštija (apie kalbas, raštiją ir knygas);

e) kasdieniai darbai (apie įvairius kasdienius darbus, pvz.: duonos kepimą, daržų priežiūrą, vaikų auklẻjimą ir pan.; apie ịvairias šventes, pvz.: vestuves, laidotuves, atlaidus ir pan.).

Kodèl taip svarbu išryškinti temas? Tai daroma dẻl to, kad kiekvienas kuriamas tekstas yra proto kūrinys, visa esme susijęs su gyvenimo patirtimi, vedančia ị žmogų, ị kūrybą7. İrašinètojo profesionalumas (gebejjimas nepertraukti klausinejjant ir minimalus įsikišimas) leidžia atsiskleisti gyvenimo detalėms, kuriose išryškejja respondento asmenybė (vertybinès nuostatos, istorinè išgyvento laiko pajauta, vertinamieji kriterijai ir jų raida, kasdienio gyvenimo kūrybinė poetika). Perpasakodamas respondentas kuria (ne tik atkuria, bet ir perkuria, prikuria, sukuria). Tuomet iš pasąmonès sugrižta kalbos raiškos (garsų ir formų) įvairove (žodžio vaizdas, atspindètas mikrokontekste). Žagarès šnektos įrašai labai nevienodi: vienuose įrašytas ištisinis pasakojimas, kituose daug įvairių ir skirtingu įrašinètojų klausimų, kuriais išbalansuojama rimtis ir respondentas negali laisvai pasakoti (kurti teksto), o tik keliais sakiniais atsako ị klausimą. Todèl straipsnio teiginiams pagrịsti yra pateikta nevienodai pavyzdžių (nuo vieno iki kelių pavienių žodžių ar žodžių sakiniuose).

\footnotetext{
${ }^{6} 1998$ m. A. Kaikarytė apklausè vyrą (g. 1928 m.) ir moterį (g. 1928 m.), o lituanistinių studiju studentès S. Mickutė ir S. Raicevičiūtè - vyrą (g. 1930 m.) ir dvi moteris (g. 1914 ir 1936 m.). 1999 m. irrašyti šešiolikos respondenčių (g. 1901, 1902, 1909, 1911, 1912, 1914, 1915, 1918, 1920 , 1921, 1923, 1926, 1927, 1928, 1929, 1934 m.) ir respondento (g. 1924 m.) tekstai, kuriu įrašus padarè A. Laurikètytė, B. Balutytė, R. Vidmantaitė, J. Norkienė, S. Raicevičiūtè. 2003 m. Joniškio „Aušros“ gimnazijos moksleiviai užrašè 1923 ir 1925 m. gimusių respondenčių ir respondento pasakojimus.
}

7 Apie tai plačiau žr. Daujotytė 1998: 69, 269. 
Straipsnio tikslas - aprašyti pastebėtas Žagarės šnektos akcentuacines, fonetines, morfologines ir leksines ypatybes ${ }^{8}$. Tikslui igyvendinti išsikelti šie uždaviniai: a) šifruoti tarminius Žagarès ekspedicijos įrašus ir rinkti medžiagą; b) aprašyti pastebėtas tarmines ypatybes ir lyginti (kur galima ir kiek galima) su kitu Joniškio šnektų (Skaistgirio, Joniškio) arba artimų tarmių (žemaičių, šiaurès panevėžiškių) ypatybėmis; c) pateikti kalbų kontaktų (latvių ir lietuvių) atspindžius Žagarès šnektoje (kiek pastebėta įrašuose).

Straipsnyje taikomi aprašomasis ir lyginamasis metodai. Dèl kai kurių kalbinių reiškinių išsakomi hipotetiniai teiginiai, skatinsiantys atlikti tolesni jų raidos ir / ar kaitos tyrimą.

\section{ŽAGARĖS ŠNEKTOS FONETIKA IR AKCENTUACIJA: TYRĖJŲ ŽVILGSNIS IR TEIGINIAI}

Akcentuacija. Žagarès šnekta yra vaš paribyje, kur vyrauja visuotinis kirčio atitraukimas, anot A. Kaikarytės, ,žagariečiai kirti atitraukia ir iš trumpos, ir iš ilgos galūnès į bet kokio ilgumo skiemenį“ (Kaikarytė 2015: 150). Pastebi-

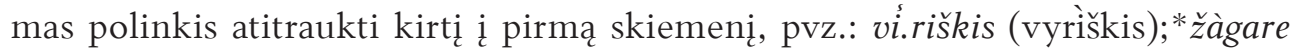
(Žagãrè), piìno.ks (pijõkas), didesni (didesni), sú.pi.ne (supỹnè), àdgal (atgaĩ), á.tmintis (atmintìs). Dèl kontaktų su latvių kalba kirčio atitraukimas turètų būti dar ryškesnis, bet dialektologai J. Pabrèža ir A. Kaikarytė teigia, kad Žagarès šnektoje kirtis nėra taip dažnai atitraukiamas kaip Skaistgirio šnektoje, kur jis nušoka į skiemenį, kirčiuojamą atraminèse formose. Tarminių įrašų medžiaga leidžia daryti prielaidą, kad atskirų respondentų kalba kiek ne kiek skiriasi: Žagarès miesto gyventojų akcentuacijos sistema paremia kalbininkų išsakytą mintị, o aplinkiniuose kaimuose (ị Skaistgirio, Raistų, Juodeikių pusę) kirčio atitrau-

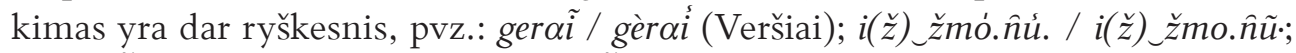
vis̀̀s $\left(\check{Z} g_{\text {g }}\right.$ / visùs; grú.dú. / gru.dũ. (Žvelgaičiai).

Minètų kalbininkų teigimu, Žagarès šnektoje ypač dažnai kirtis atitraukiamas iš veiksmažodžių ir dalyvių, padalyvių, pusdalyvių formų galinio skiemens i priešdèlius (Pabrèža 1998a: 782; Kaikarytė 2015: 152). Tokią minti paremia ir Žagarès šnektos pavyzdžiai, plg.: nèžinaú, ùšteg̉k, pàsirink̂t̂̉ žàgarú., valdítoiei pàskirrti (Žg). Jei veiksmažodis turi du ar daugiau priešdèlių, pastebi A. Kaikaryte, kirčiuojamas arba priešdẻlis, einantis prieš šaknị, arba tas žodžio skiemuo,

${ }^{8}$ Dèl pernelyg didelès šio straipsnio apimties Žagarès šnektos morfosintaksinèms, sintaksinèms, frazeologinèms ir stabiliųu junginių ypatybėms atskleisti autorès rengiamas atskiras straipsnis. 
kuris gauna kirti asmenuojant. J. Pabrèžos nuomone, „kirtis prieš žodžio šakni gali būti atsiradęs dèl analogijos su veiksmažodžiais, kurių priešdèliai turi dèsningą morfologinị kirtį, pvz.: nebęà̀kalba, nebępàmenu“ (Pabrèža 1998a: 782; Kaikarytė 2015: 153). Pastebèta, kad „tarminèje literatūroje [...] apie Skaistgiri (taip pat Žagarę, Gaižaičius), kaip ir gretimame žemaičiu plote, labiau pabrèžiamas pirmasis tvirtagalių dvigarsių dèmuo (LKT chr.: 63)“ (Kaikarytė 2015: 156-157). Tą mintị paremia ir pavyzdžiai iš žagariškių tekstų, pvz.: pẽ. Ins, par_ta.gã. îsra., pamĩ. $\tilde{y} k l \alpha s^{9}$.

Apie akcentuacijos sudėtingumą A. Kaikarytė yra rašiusi taip: „Ypač sumišęs Skaistgirio šnektos kirčiavimas - jame susipynusios ir vadinamojo aukštaitiškojo, ir žemaitiškojo visuotinio kirčio atitraukimo ypatybès. Tvirtagalès priegaidès spūdis dvigarsiuose koncentruojamas nenuosekliai - ir ant pirmojo dèmens, kaip Žagarès šnektoje, ir ant antrojo dėmens, kaip Joniškio šnektoje“ (Kaikarytė 2015: 170-171). Tai rodytuc ir pavyzdys iš Žagarès: nu_tai_tén [šokiuose] ka_pri-eídava / vìsà *žàgarè búddava (Žg). Vis dèlto galima kelti hipotezę, kad dvigarsiuose tvirtagalès priegaidès spūdis pasiskirsto per abu dèmenis, pvz.:

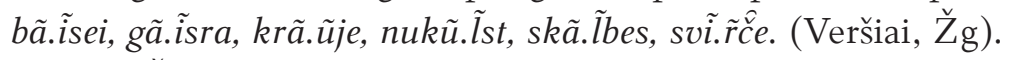

Taigi Žagarès šnekta kalbančiųjų respondentų akcentuaciją yra keblu aprašyti. Primintina, kad ją iki dabar tebeveikia ne tik kalbiniai kontaktai, bet ir du kalbiniai standartai - latvių ir lietuvių radijas bei televizija.

Fonetika. Svarbiausios vaš fonetinès ypatybès, kurias išskiria dialektologai, yra sveikų mišriųjų dvibalsių an, am, en, em, nosinių balsių $q$, $e$ išlaikymas ir $l$ kietinimas prieš $e, \dot{e}, e i, e$ tipo balsius. Žagarès šnektos tekstuose šiu ypatybių

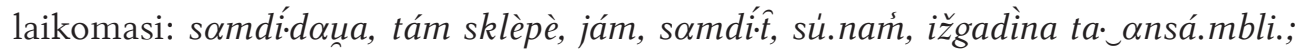

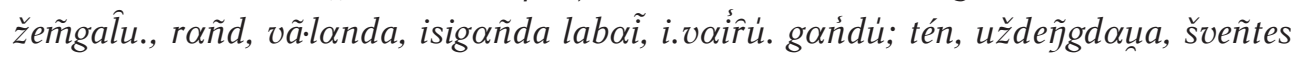
rúoždoúa, rajòna ceñtras; sodi.bẹ:łas (Žg, Veršiai, Žvelgaičiai, Žiuriai). Dialektologai J. Pabrèža ir A. Kaikarytė yra pastebėję, kad apie Žagarę „gana dèsningai kietinamos junginių grupès $l \dot{e}, l e, l e$, lei nekirčiuotose galūnėse ar galūnėse, iš kuriu atitrauktas kirtis, ypač žodžiuose ir formose, padarytose iš veiksmažodžio leisti“ (Pabrezža 1998a: 786; Kaikarytė 2015: 163). Kaip yra pastebejjusi

\footnotetext{
${ }_{9}$ Tradiciškai nuo 1970 m. publikuotuose tarminiuose tekstuose iš Žagarès tvirtagališkai kirčiuotinų dvibalsių ir dvigarsių skirtingais kirčio ženklais (riestiniu ar dešininiu) žymimas tik pirmasis dvigarsio ar dvibalsio dèmuo, plg.: lãika, nusigãndus (Lkt 1970: 149); vá.ika, ké.lmai (Lktch 2004: 68-69). Skaistgirio šnektos aprašo pavyzdžiuose vartojami abu kirčio ženklai; plg.: bã.isẹi, plã.nta, sẹptí.nta (Kaikarytė 2015: 151-152). Autorè, šifruodama tekstus, pastebėjo, kad pirmasis dvibalsiu ir dvigarsių dėmuo yra ryškesnis, bet ir antrasis dėmuo turi kirtį. Todèl pavyzdžiuose tvirtagale priegaide kirčiuojamų dvibalsių ir dvigarsių dėmuo žymimas kaip pusilgis ir kirčiuojamas riestiniu kirčio ženklu. Antrasis dèmuo taip pat kirčiuojamas riestiniu, bet nežymimas pusilgumas.
} 
A. Kaikarytė, Žagarès šnektoje kietinamas tik junginys le, tik jis, kaip ir skaistgiriečių, žodžio viduryje nekietinamas (Kaikaryte 2010: 12; 2015: 164) ${ }^{10}$.

Atrodo, kad kalbininkų teiginiai yra pernelyg kategoriški. Polinkis kietinti le grupès jungini galūnèse tikrai dažnesnis, plg.: dabar̃ melorã.ciie nùšlave tuõs / ré.iške / visà(s) sodi.bẹ́las (Žg); gatvã.la tòkì śæũra / su_aŕkleís važúodava / pripuśtí.dava (Žg); dí.rbau / kæútà(š) šẹ́ræxu / ká.rves mí.lžau (Daukšiai); paŝú.dava

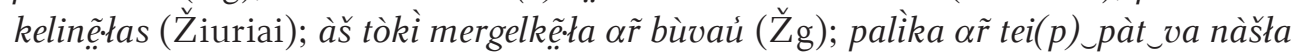
$(\check{Z} \mathrm{~g})$; àtnešu dúonas riekẽ.ta. (Žg). Pavieniais atvejais $l$ kietinamas ir žodžio šak-

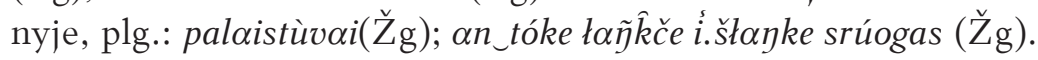

Tarmėtyrininke A. Kaikarytė, aprašiusi Skaistgirio šnektą, yra paminëjusi ir keletą Žagarés šnektos ypatybių, kurios sietinos ir su Joniškio šnektos ypatybėmis (Kaikarytė 2010; 2015). Pirmiausia minètina žemaitiškoji galūnių redukcija: „Žagariečiai netaria pralietuviškų trumpųu balsių tose linksnių ir asmenų galūnėse, kurios niekada nekirčiuojamos, išskyrus tuos atvejus, kai balsiui iškritus susidaro sunkiai ištariama priebalsių samplaika“ (Kaikaryte 2015: 150). Teigini paremia įrašuose girdimi káims, brã.vors, viens, vé.l̂ns ir pan. Kalbininkès teigimu, „vietoj pralietuvių ilgųjų *-a, *-as, *-e, *-es žagariečiai nekirčiuotose galūnèse turi trumpuosius balsius [-a], [-as], [-e], [-es]“ (Kaikarytė 2015: 150).

Minètų kalbininkų pastebėta, kad kirčiuoti pagrindiniu kirčiu balsiai $a$, $e$ nepailgejja, o tariami trumpi, plg. Žagarès šnektoje: vèŝ́t, uždêk̂t, anà, bràstva, màna. Trumpumas čia galèjo atsirasti dẻl kalbų kontaktų, manoma, kad dẻl latvių kalbos įtakos (Pabrèža 1998a: 783; Kaikarytė 2015: 157).

Balsiai $i, u$ pailginami iki pusilgių. J. Pabrèža yra pastebėjęs, kad Žagarès šnektoje tokios pozicijos $i$, $u$ savo kokybe „daugiau primena rytiečiu pusilgius, negu suvalkiečiu trumpuosius“ (Pabrèža 1998a: 784; Kaikarytė 2015: 158). Teiginys taip pat koreguotinas, nes minètus balsius respondentai linkę dèsningai pailginti tik mišriuosiuose dvibalsiuose ir dvigarsiuose (pvz.: nebedí.rp̂t̂, ši.mta, bú.gkeri., iždú.rdava). Kitais atvejais trumpujų $i, u$ tarimas įvairuoja: gali ir pailgèti (pvz.: netú.r̂ ; virš_trí.zdešimt mẽ.tu.; paskuti.neis), ir nepailgèti (plg.: mìtus [sulaukusi trisdešimties metu]]; pìnigus; pri_rùsu; medines (medinès); mišsks; palaistùvai; palika [tapo]; apatìnei aũkštai; rùdeni.).

Žagariškiai veiksmažodžio eiti šaknyse $e$ keičia $a$, todèl sakoma ain. Tais atvejais, kai veiksmažodis vartojamas su priešdèliu nu-, su-, besibaigiančiu balsiu, ịspraudžiamas $v$, pvz.: nuveínù (Žg); o_dàbà ta_màm(a) an_to_dúonas kvepệii-

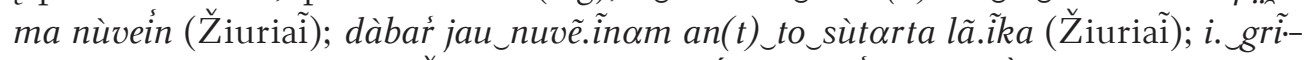
bas mamã.te nuvẽ.ĩdova (Žvelgaičiai); kaimínai sùveín tén / gìmines [ị metines] suvažúoj (Žg); dàbà víens pas_ki.ta. nè / [seniau] suveĩdava / pavakaró.j (Žg).

${ }_{10}$ Apie junginio $\overline{l e}$ kietinimą tarmese plačiau žr.: $\overline{\text { Kardelis }} 2002: \overline{107-1} 14 ; \overline{2002}: \overline{215}-\overline{222} ;$ 2008: 485-494. 
Su $j$ dèsningai tariamas žodis ilgas, plg.: ta(i) jũu. [avių] ví.lna írà î̃. lóga (Veršiaĩ); i_ta_ká.ritis î̃. Iga / prìkiši nàgùs i_sùpas (Žg).

I priebalsiu samplaikas $r z$, lt įterpiamas $a$ arba $e$, plg.: bú.dova tókes karazín-

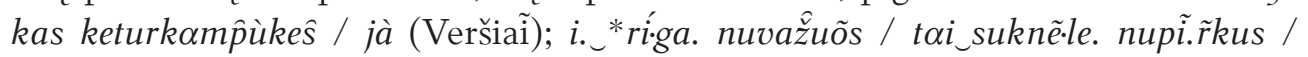
toi_pã.leta. (Žg), panašiai kaip užrašytas dar Mato Slančiausko katanas SŽ ar kazalèkas $\mathrm{Kr} \check{Z ̆}^{11}$.

Žodyje geležis, šulinys ir jo vediniuose išmetamas balsis $e$ arba $i$, plg.: priká.l-

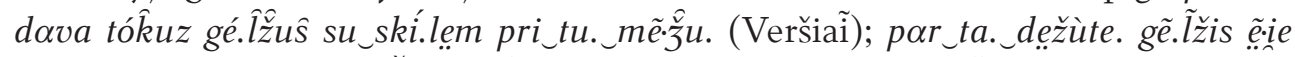

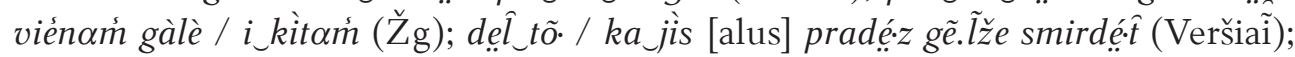

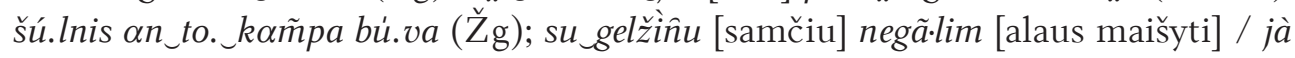
(Veršiaĩ). Naujai atėjusiuose i̇ šnektą žodžiuose balsiai gali būti visai netariami [gródava víens kardijóns ir_bú.gnas (Veršiai); vệ. lé.rma / bé.gdavau i._ká.ima. $(\check{\mathrm{g} g})$ ] arba keičiami kitu balsiu [gi.valùku (Veršiai, Žg); ká.ršt(a.) ã.kmina. í.ded $i_{\smile} t(a \cdot) \_\tilde{a} \cdot l u$. (Veršiai); bùva acirã.du(s) ski.lùte. tòki / tai_vã.î́kai / sã.ka / mèz-

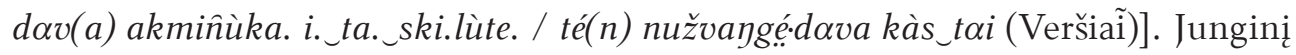
va žagariškiai, panašiai kaip žemaičiai, taria kaip dvibalsį uo žodyje apvalus, plg. dilginệ.le / tòkié lã.pai apuõlu.s (Žg).

Iš M. Slančiausko užrašytos tautosakos žinomas ir dabar tebetariamas dvigarsis in vietoj ilgojo balsio $i$ žodyje knyga, plg. tiktaíjeu kní.ngas nusipírk̂t reiké.ie $(\check{Z} g)^{12}$.

Šlekiavimas - ryškiausia ne tik Skaistgirio, bet ir artimos, Žagarès, šnektos ypatybè. Apie šlekiavimą Skaistgirio ir Žagarès apylinkèse yra raše dialektologai A. Jonaitytė, Zigmas Zinkevičius, A. Girdenis, J. Pabreža (Jonaitytė 1960: 79-86; Zinkevičius 1966: 148; Girdenis, Pabrěža 1978 (= Girdenis 2000: 117120); 2002: 229-232; Pabréža 1998: 25-27; 1998a: 781-787). Dèl šios ypatybès minètų šnektų atstovai mokslinėje literatūroje vadinami šlekiais. Kelta minčių, kad aptariamas reiškinys galèjęs būti paplitęs didesniame plote, jo pẻdsakų pastebèta ir gretimame Rudiškių šnektos plote (Urnėžiūtė 1999: 21-23; Kaikarytė 2015: 159).

Pirmoji, plačiau rašiusi apie šlekiavimą, kalbininkė A. Jonaitytė senuoju šlekiavimo variantu laike priebalsiu $s$ ir $\check{s}, z$ ir $\check{z}, c$ ir $\check{c}, d z$ ir $d \check{z}$ nedésningą vartojimą (Jonaityte 1960: 79-86), kai vietoj š, $\check{z}, \check{c}, d \check{z}$ tariama $s, z, c, d z$ ir išimtiniais atvejais vietoje $s, z, c, d z$ tariama $\check{s}, \check{z}, \check{c}, d \check{z}$. Disertacijoje „Šakynos tarmé“ (1962) A. Jonaitytė yra pastebejjusi, „kad Gražáičių ir Domeĩkių kaimuose vietoje bendrinès kalbos $s, \check{s}, z, \check{z}$ tariami tarpiniai $s, \check{s}$ ir $z$, $\check{z}$ garsai, kurie yra artimesni $\check{s}, \check{z}$ negu s, $z$. Bet darydama išvadas kalbininke liko prie nuomonès, kad

${ }_{11}$ Žr.: SŽ 2014: 282 ; KrŽ (rankraštis).

12 Žr. SŽ 2014: 305. 


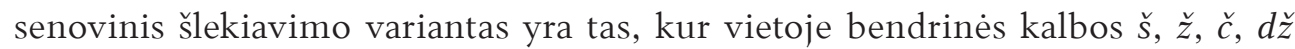
tariami s, $z, c, d z^{\prime \prime}$ (Kaikarytė 2015: 159).

Praejjus dešimtmečiui, po 1975 ir 1992 m. ekspedicijų i̇ Žagarę bei jos apylinkes, A. Girdenis ir J. Pabrèža pradejo tvirtai teigti, kad „keliuose Žagarès apylinkès kaimuose (Martỹniškiai, Brùžas, Žvelgáičiai, Dilbinẽliai, Veršiaĩ, Žiùriai, Stungiai, Daukšiaĩ) priebalsiai $s: s ̌, ~ z: \check{z}, \check{c}: c, d z: d \check{z}$ yra nemaišomi, o suliejami i vieną tarpini garsą ś, ź, ć, ž “ (Girdenis, Pabrèža, 1978 (= Girdenis 2000: 117120); 2002: 229-232; Pabrèža 1998: 25-27; 1998a: 781-787). Dažniausiai, rašo A. Kaikarytè, ,suliejami ị tarpinį $s, s ̌$ garsai. Rečiau $z, \check{z}, c, \breve{c}$ ir $d z$, $d \check{z}$, nes žodžių su šiais priebalsiais yra kur kas mažiau“ (Kaikaryte 2015: 159). A. Girdenio ir J. Pabrėžos jau 1978 m. konstatuota, kad šlekiavimas Žagarès apylinkėse gerokai apnykęs (Girdenis, Pabrèža, 1978 (= Girdenis 2000: 120); Kaikarytė 2015: 162). Kalbininkų teigimu, šlekiavimas nẻra kildintinas iš žiemgalių kalbos. Kadangi nėra išlikusių žiemgalių rašto paminklų, sunku ịrodyti, kad patys žiemgaliai neskyrè sargiųju (s tipo) nuo žvarbiųjų (š tipo) priebalsių. Be to, neįrodyta, kad lietuvių kalba pati neturėjo tarmių, neskiriančių šių priebalsių (Girdenis, Pabréža 2000: 231; Garšva 2005: 225). Pastarieji kalbininkai yra užsiminę, kad šlekių tarpiniai garsai gali būti labai archajiški - „galbūt išlaikyti net iš tų laikų, kai vietoj dabartiniu š, ž tebebuvo vartojami guturaliniai priebalsiai“ (Girdenis, Pabrèža, 1978 (= Girdenis 2000: 119); Kaikarytė 2015: 163). Liekamųiu šlekiavimo reiškinių Žagarès šnektoje tebesama, plg.: aź gí.̌̌̌euś śu_viśkóo.(m) / muśtê.lẹm (Žg); àćśkirai pasaki.śu (Žg); o_dàbà viśkaś kaîp i_ne_śàva $(Z ̌ \mathrm{~g})$; añź dí.rba pri_śtatí-

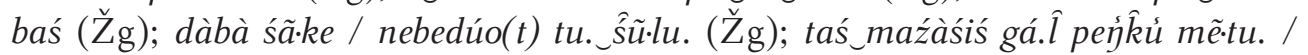

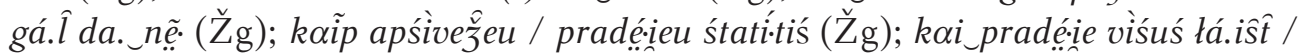

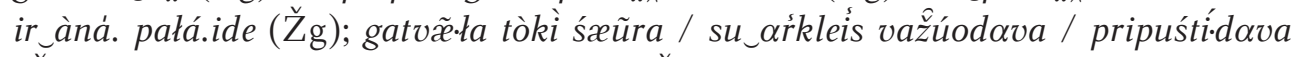

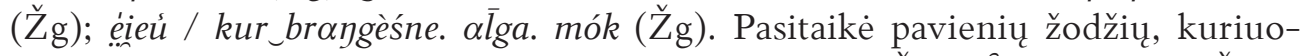
se žvarbusis š visai netariamas, plg.: vá.isina [vaišino] (Žg); ŝlũ.ba [šliūbo] (Žg).

Fonetiniai žodžio kitimai neretai būna nulemti artimosios ar tolimosios asimiliacijos, plg.: rùšiškai (Veršiai); apśiplá.unu / iśiślúostau če_ta·ví.rtuve. (Žg); nu_ir_daúgæxu / k̂róx.udavom śu_śàkè / vìsa. diena. k̂ró.vẹm (Žg); šušá.ude nàmùs / kitùs nudê.gina (Žg); netó.lì pá.rkẹs atệ.ie šu_šá.utuvais i_nuvã.re [žydelkaitę] (Žg); išišukúodava tas_ví.lnas (Žg).

Pastebèta, kad vyresnieji Žagarès šnektos, kaip ir kitų tarmių, atstovai priebalsius $c h, f, h$ taria $k, p, g$, plg.: eĩdavom i._pẽ.r̃mas (Daukšiai); tuos_veřšèlùs

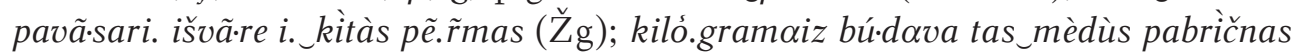
(Žg); [Barboros žagarietès kapą] išníekina kaškòkié kuligànaí (Žg); dàbà ír pudã.mentai (Žg); pirkaú plenèlùs / pasidàræú pó.rmas / ŝúdavau / ŝuvaũ(š) šlæuštinùkus (Veršiaĩ) ${ }^{13}$.

${ }_{13}$ Apie panašius kitimus Skaistgirio šnektoje žr. Kaikarytė 2015: 164. 
Fonetinės ir morfologinès Žagarès šnektos ypatybės

(XX a. pabaiga - XXI a. pradžia)

1 DIAGR AMA. Žagarès šnektos fonetinių kitimų nuorodos
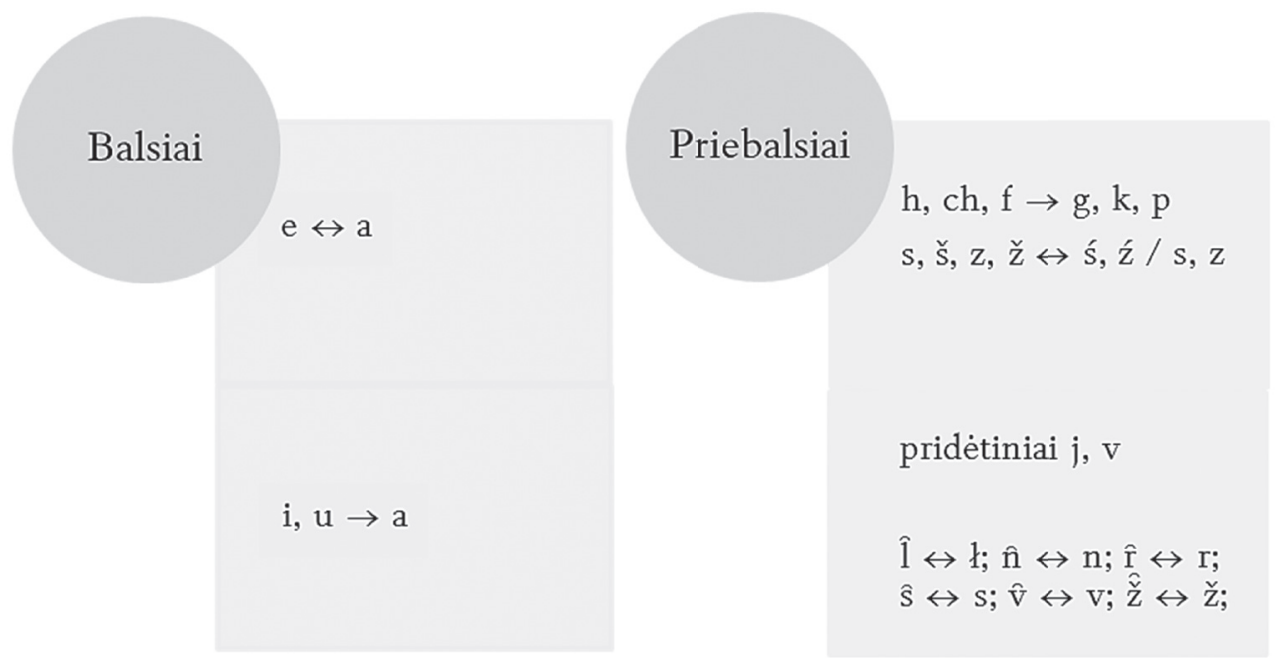

Žagariškiai ir priebalsius ar jų samplaikas linkę keisti, pvz.: vl taria $b$ [màna

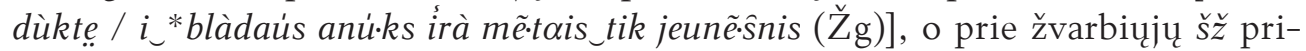

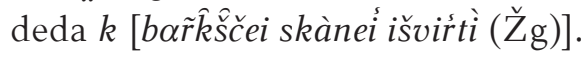

Kaip ir kiti Joniškio šnektų atstovai, žagariškiai linkę numesti nekaitomų žo-

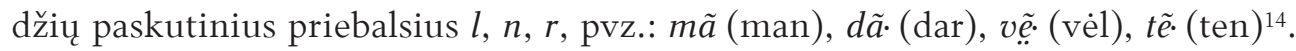
Tačiau teigti, kad visi respondentai dèsningai numeta minètus priebalsius, neleidžia viena aplinkybè. Dèl nenuoseklaus pasakojimo (nuolatinio įrašinètoju klausinejjimo ir pasakojimo pertraukinejjimo) respondentas negali atsipalaiduoti ir taikosi prie standartinès kalbos normų.

A. Kaikarytės teigimu, žagariečiai ,,išlaiko sutrumpėjusių žodžių priebalsių minkštumą žodžio gale“ (Kaikarytė 2015: 164). Tai vyksta labai nedèsningai ir galètume sakyti, kad tik pavienių respondentų kalboje. Atrodo, kad minkštinimas dažnesnis žodžio šaknyje ar viduryje, plg.: màmà bùva laimí.nga / kad_ànà pã.r̃neše vaiká.ms ta._plùta. (Žiuriaĩ); [žydu] vìsas k̂r̂́xutuves bùva (Žg);

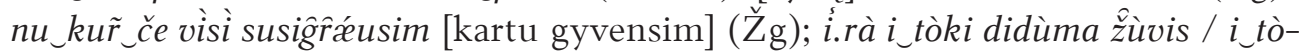
ki (Veršiaĩ); prîk̂ræũs / arba_naštê.le. uždẹs an_pèčù. / eínì [su malkom] (Žiu-

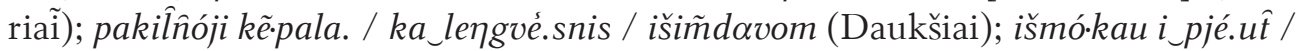
i_vežimus k̂ré.ut (Žagarè); k̂r̂́x.utuve bùva *juodeîkuos pas_*arlá.ucka. (Žg); [ru-

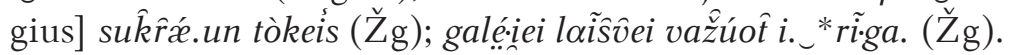

Naujai ì šnektą atėję žodžiai pritaikomi ir fonetiškai: griñdas iždažitas /

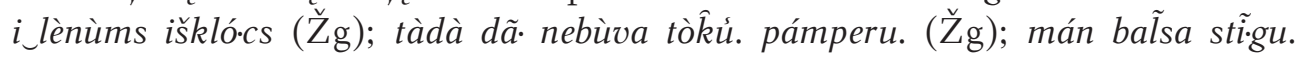

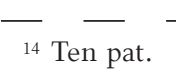


matarãcije bùva (Žiuriaĩ). Yra pavienių žodžių, kuriuose $t$ neverčiamas č. Panašiai kaip žemaičiai, senuosiuose skoliniuose žagariškiai išlaiko priebalsị $t$, plg.: *kũ.tes la b̂ũ švẽ.zdava (Žiuriai); niékina bažnĩ.tes [prie ruso] (Žiuriai). Pagrindiniai fonetiniai Žagarès šnektos kitimai nurodyti 1 diagramoje.

\section{ŽAGARE்S ŠNEKTOS MORFOLOGIJA IR ŽODŽIŲ DARYBA: İŽVALGOS IR POLINKIAI}

Aprašomosios Žagarès šnektos gramatikos kategorijos plačiau aptariamos pagal savarankiškas kalbos dalis - vardažodžius ir veiksmažodžius. Tik iš dalies paminimos tarnybinès kalbos dalys, nes, autorès nuomone, prielinksnines konstrukcijas, dalelyčių vartojimą ir pan. dẻl reikšminių ypatybių tikslingiau aprašyti numatomame straipsnyje apie žagariškių sintaksę.

Žagarès šnektos daiktavardis aptariamas morfologinių formų ir kategorijų bei darybos atžvilgiu. Tarminiuose įrašuose pastebimas kiek gausesnis $-i$ ir $-(i) u$ kamieno daiktavardžiu vartojimas, pvz.: tik_rùdeneis [pjaudavo kiaulę] (Žvel-

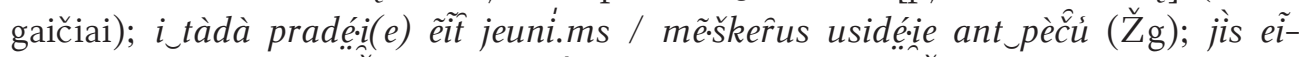

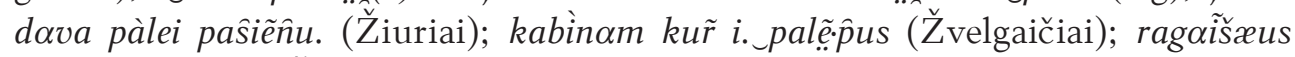
jeu_nèkxp niẽks (Žg). Pavienių tikrinių daiktavardžių taip pat vartojamos -(i)u kamieno formos, plg. *stàs̀us (Žg). Pastebėta, kad atskiri daiktavardžiai (kiné, sèmena, cukras) yra - $\dot{e}$ ir - a kamieno formos, plg.: par_ta. kìnes àpače [pabègo] (Žiuriai); cùkra dê.dam (Žvelgaičiai); im̃dava lã.ũkan ta(s)_sẹ́menas (Žvelgaičiai).

Savita yra Žagarès šnektos daiktavardžiu giminès kategorija. Antai religinių švenčių pavadinimai, kiek pastebèta, yra vyriškosios giminès, pvz.: Šeštinis, Sekminis, Devintinis. Pavienès vietovardžių formos taip pat vartojamos vyriškąja gimine, ypač vietų, esančių toliau nuo Lietuvos (Amerikas, Argentinas), pvz.: *amèrike ižbùva dê.ši $(m)$ mê.tu. (Žg); brólle sú.nùs paré.ies iš_*argentina bùva (Žg). Dar iki dabar tebevartojama moteriškosios giminès forma Joniške, nes priesagos -iške vediniu Joniškio krašte itin daug, plg.: víena. síki. toi ${ }^{*} * j o ́ n$ niškei èsù gulẹ́.ius

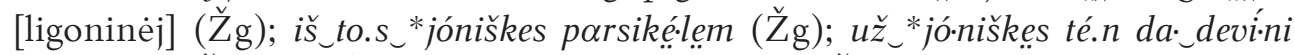

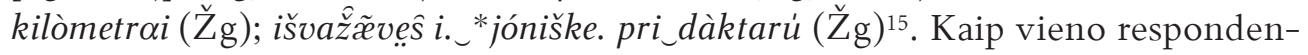
to pasakojime taikomasi prie bendrinès kalbos vietovardžio formos, rodo saki-

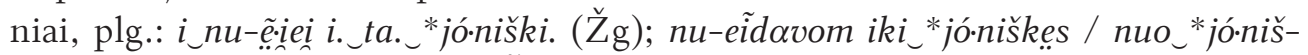
kes / i._*meitene. / i_apliñkui $(\check{Z} g)^{16}$. Tarminès ir kitos vardyno formos, pvz.: čè

15 Žr. Bartkutè 2008: 36; 48; 90; 128; 158; 159; 171, 224.

16 Apie vardyno formų Joniškis ir Joniške svyravimą žr. Jšpt, 2001: 37. 
mũ.su. *švẽ.dlauke [oficialiai - Švedlaukis] (Žg); iš_*pakrúojeus [oficialiai - Pakruojis] rajòn(a) atkệle čè (Žg); * ró.čkei bùva / *miknã.čei / daúgæxú *riklã.čei bùva

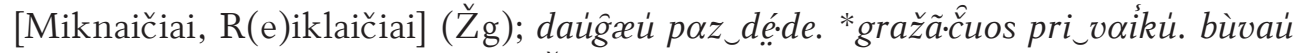
dù mètù [oficialiai - Gražaičiai] (Žg). Ir vardo forma Ignas vartojama moteriškąja gimine: ĩneše mùmis taz ${ }^{*} b r o ̀ n u(s) ~ s u \_t u o \_* \grave{g} n e$ i._lóva. (Žg).

Kaip yra pastebėta Joniškio šnektų tyrèjų, giminès svyravimai dar ryškesni vartojant bendrinius daiktavardžius. Jie pagrečiui pasakomi ir vyriškąja, ir moteriškąja gimine: alyva ir alyvas, saldainis ir saldaine (Jšpt, 2001: 37). Žagarès šnektoje dar ryškesne bendrinių daiktavardžiu moteriškosios ir vyriškosios giminès opozicija. Tarkim, daiktavardžiai brogè, parkè, gubè, gryba, suknè, pakulès yra moteriškosios giminès, pvz.: kas_mê.ta. papúoždava naújom sùknẹm (Žg);

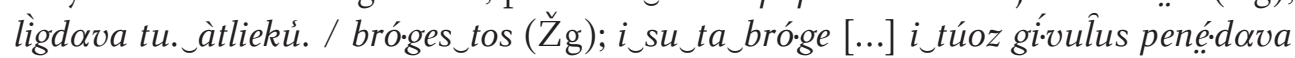
(Žg); če pá.rkej suvažúnodova iš_*jónišske mã.šinos / kíek čè žmón̂u. bùva (Žg);

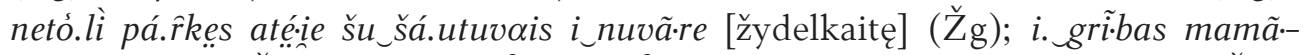
te nuvẽ.ĩdava (Žvelgaičiai); pệ̆ùùùs tòkùu(s) sùrišam / sustã.tom i. gùbès (Žg); pã.kuless (Žg). Daiktavardžiai knopkis, cukras, pagalvis, pamiškis yra vyriškosios giminès, pvz.: paspá.udei tókki. knòpki. / jeĩgu par_švilpi. eĩn / pràded jì (̌̌) švệlp̂t / toi_eĩn gã.rs laũka / tai_tàdà jeu_gál paléiŝt vis̀̀s ràtùs / ka_jis [dampis] pradẹ́tu. sùk̂̂t ta. mašina. kùlæma. (Veršiaĩ); nóri làbaí stìpraús [alaus] / gàlì cùkra

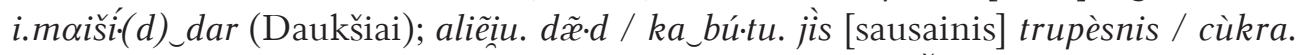
gàli dệt.tva (Veršiai); sènæú kiló.grams cùkra bùva lìcs (Žg); àle pagá.lve nedúo-

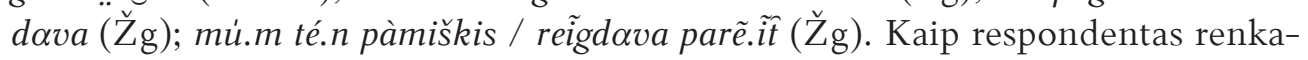
si daiktavardžio giminę, galima pastebėti sakiniuose, kuriuose daiktavardis yra neseniai atėjęs, t. y. naujažodis, plg. daiktavardžio karjeras giminès svyravimą vieno žmogaus pasakojime: té.n karjèras kã.se / tai_čè pasistã.tẹm (Žvelgaičiai);

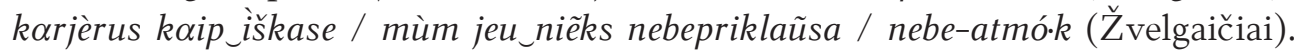
Vis dèlto žagariškiai respondentai naujažodžius linkę vartoti moteriškosios gimi-

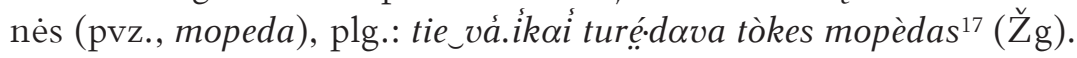

A. Kaikarytė, tyrusi Joniškio šnektas, yra pastebejjusi daiktavardžių linksniavimo polinki paprastėti ${ }^{18}$. Šie procesai būdingi ir Žagarès šnektai: „Tendencija pereiti nuo trijų linksniavimo tipu prie dviejų susijusi su daugumai fleksiniu kalbų būdingu polinkiu diferencijuoti fleksines klases pagal gimines“ (Kaikarytė 2010: 118). Perejjimas būdingas daiktavardžio daugiskaitos formoms, pvz.:

17 Jei žodis turi šalutinị kirtị, dvibalsio abu dèmenys kirčiuojami vidurine priegaide.

18 A. Kaikaryte, palyginusi Joniškio šnektos fleksinių formų paradigmas, pastebėjo, kad „Joniškio šnektoje yra 1) daugiau negu bendrinèje kalboje sinkretizuotų linksnių formų; 2) mažesnis gramatinių morfemų alomorfų skaičius; 3) daugiau neikoniškų formų negu bendrinejje kalboje; 4) ryški tendencija nuo trijų (vyriškojo, moteriškojo ir mišriojo) linksniavimo tipų pereiti ị du (vyriškąji ir moteriškąii) linksniavimo tipus“ (Kaikarytė 2010: 118). 
su_pá.mainom tai_turẹ́dava bú.t̂t kèturì žmõ.ni.s ant_mašìna (Veršiaĩ); o_aštúo-

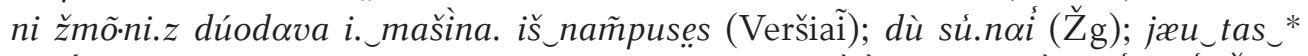

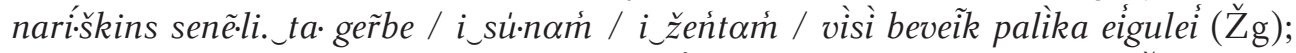

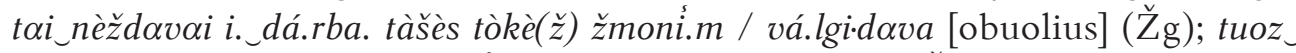
belá.iŝ̂uus vó.kečei bùva žmoní.m [atidavę] / ka_dir̃ptu. (Žg); mašiniêris pasã.ke

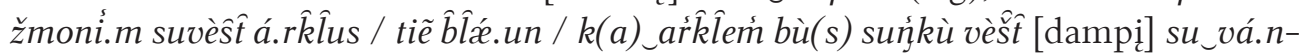
den̂u (Veršiaĩ); vá.ndene pripíle žmoni.m nusipraũŝ̂t / nusišlúost̂i. $\hat{t}$ (Veršiaĩ); su su-á.ugusei(ž) žmònim dí.rbau (Žiuriaí); ka_jeu_piétai / pavá.lgi.dovau (Žvelgaičiai); piétaḿ daugx́.use ŝr̂̀bà bú.dava (Žvelgaičiai).

Žagarès šnektoje, kaip ir kitose lietuvių kalbos tarmėse, svyruoja ir daiktavardžiu skaičius. Pavyzdžiui, minètinas daugiskaitinès formos daiktavardžio šienai vartojimas, būdingas ir pietu žemaičiams, reikšmėmis 'šienavimas' arba 'nupjauta žolè', plg.: visas pàkraští.s pagal_*tî.reli. té.n bùva šiénấ (Žg); [kolkoze] tu._šiénú. nebùva / tos_ká.r̂ves pùse mẽ.tu. bú.dava uštrùkuses (Žg); gi.vẽ.nimz

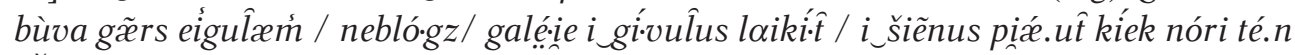
$(\check{Z} \mathrm{~g})$. Respondentai vartojo vienaskaitinę daiktavardžio formą vestuvé, plg.: dvi savá.ite(š) švẽ.zdava vestú.ve. (Veršiaĩ); àš tik_sàva vestùvei [dariau alų] (Veršiaĩ). Vienaskaitinès daiktavardžiu formos kartais pasirenkamos apibendrinimui nu-

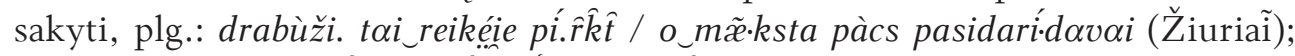

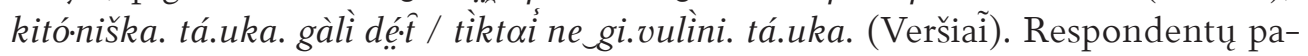
sakojimuose pramaišiui ir itin stilistiškai motyvuotai vartojamos ir vienaskaitinès, ir daugiskaitinès formos. Vienais atvejais galima įžvelgti apibendrinamąją reikšmę ir priešpriešą su kitu, įvardijamąją reikšmę turinčiu, žodžiu, plg. má.lka / ti_iñune_má.lka / žãabai (Žiuriaĩ). Kitais atvejais įvardijamieji žodžiai, galima būtų manyti, derinami vienas prie kito, plg. a_žùviés taúkaí / margarìnai / tàs_jeu nebe_iž_gívule (Veršiai). Pagaliau ir daugiskaitinèmis formomis respondentai gali nusakyti apibendrinimą, plg.: víenos móteriškoz gi.vẽnom / nebùva àlú.

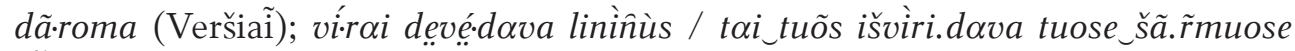
(Žvelgaičiai).

İrašuose pastebètas įnagininko linksnio trumpinimas ir paradigminių santykių išlyginimas, plg. jà / su_svî.řčce [šuliniai būdavo] (Žg).

Žagarès šnektos priesaginių daiktavardžių vedinių dažniausiai daromasi su priesagomis -atis, -ëjas, -elis, -ietis, -tojas. Priesagos -atis (greičiausiai trumpinys iš -aitis) vediniais (tikriniais žodžiais) nusakomi vietu pavadinimai (vietovardžiai), plg.: *gražã.č́uos nẹ. parduotùves (Veršiaĩ); *ró.čkei bùva / *miknãčei / daúğæú *riklã.čei bùva [oficialiai - Miknaičiai, R(e)iklaičiai] (Žg); daúĝxæú paz_dẹ.de. *gražã.č̀uos pri_vaikú. bùvaú dù mètù [oficialiai - Gražaičiai] (Žg). Tos pačios -atis vediniai (bendriniai žodžiai) įvardija asmeni pagal giminystę, pvz.: mamã.te vẽ.r.rbdava tiem_ú.kinigkam (Žvelgaičiai); mamã.te čè su_sèsè gi.vê-na (Žg); tai_da._mamã.te mẹ.nesi. gi.vẽ.na (Žg); mamã.te pali.dẹ.ie (Žvelgaičiai). 
Galima įžvelgti minètų priesaginių vedinių mažybinę-maloninę reikšmę, kuri perteikiama gausiais vediniais su kitomis priesagomis, tokiomis kaip: -elis, -ičkas, -(i)ukas, -utis. Priesaginio daiktavardžio reikšmė išryškejja iš mikrokonteksto - sakinio. Priesagą -elis respondentai pasirenka emociškai paveikesniam vaizdui ar nemalonius prisiminimus keliančiam objektui nusakyti, plg.: sæubẽ.lei / kaĩp suýkù bùva (Žiuriai); tàdà pã.r̃davẹm ta·laužêelli. [tèvų sodybą] (Žg). İvardijimui pagal amžiu, brandą vartojamas priesagos -ičkas vedinys, pvz.: tòkez grã.že(ž) ži.delkičkas / su_kàsó.m / kai_letùveś / jà (Žg). Gausiausia ịrašuose maloninių daiktavardžiu su priesaga -(i)ukas vedinių, pvz.: jis [kombainas] pagá.un

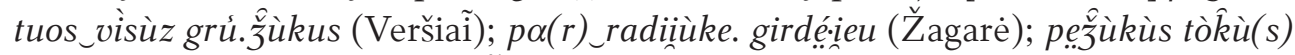

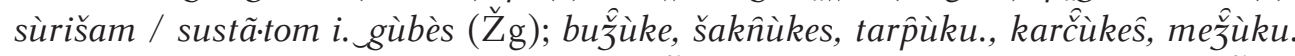

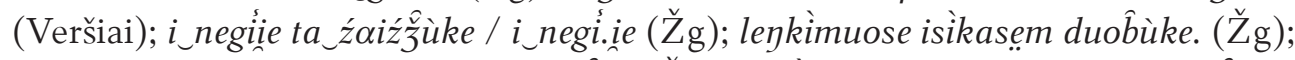
su_mašiñùku sumá.ldava tuos_óbuolus (Žg); palika sèseŕs vaĩgz dveiñu. meč̀uku. (Žg); sen̂ùks (Veršiai); mokin̂ùke iš_mokî.klas (Žg). Mažybiniu -ukas daiktavar-

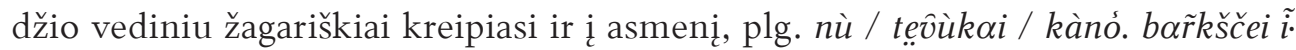

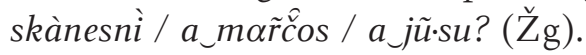

Vardažodinę ypatybę žyminčios priesagos -iene daiktavardžiais nusakomi valgių (sriubų) pavadinimai, pvz., sènæú bú.dava pú.ŝri.ti.(s) stiprá.usis / piétaí ir̃gi / vakaríene / baltà ŝrùbà / krúopas / a`kleckíene / a`bulbíene (Žg).

Priesaginiai veiksmažodinės ypatybės turètojus įvardijantys daiktavardžiai su priesaga -ëjas, nusakantys asmens veiklą, pomėgius ir pan., turi galūnę /-is / ir /-as/, plg.: tas_pirkẹiis visíem skó.lú. palika / dệie i_voketiìe / ir iždẹ.ie (Žiuriaĩ);

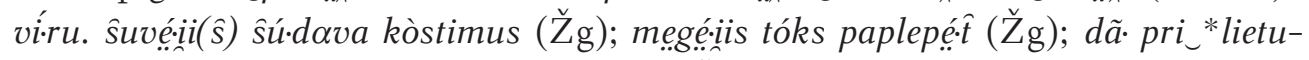
võ.s / *str̂̀uliz bùva vedẹ.inis / ži.dê.lis (Veršiai).

Daiktavardžių vediniais iš vietovardžio su priesaga -ietis žagariškiai, kaip ir kitos Joniškio šnektos, įvardija asmenis pagal jų kilimo ar gyvenamąią vietą,

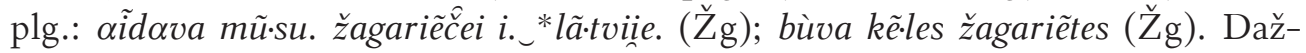
niausiai tokiais daiktavardžiais nusakoma neapibrèžta vieta, plg.: parsikệ̂læxu čè /

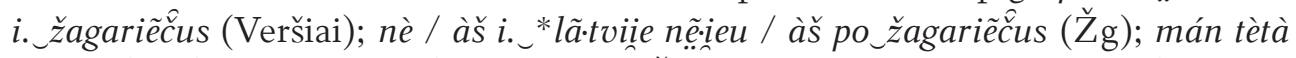

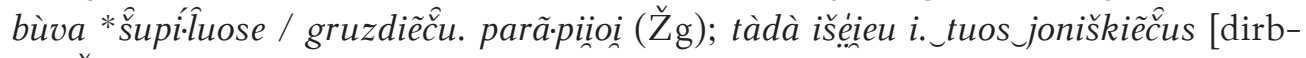
ti] (̌̌g).

Žagarès šnektoje priesagos - $(t)_{o j-}$ vediniai, įvardijantys asmenis pagal profesiją, kur kas dažniau vartojami su galūnèmis /-is/ arba $/-a s /{ }^{19}$, pvz.: sú.nùz gídi.tojis (Žg); mó.ki.tojis atvažú.odava (Žiuriai); bùva tòks *kuprẽ.vič́uz gí.-

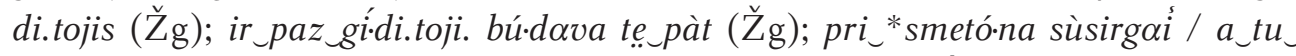

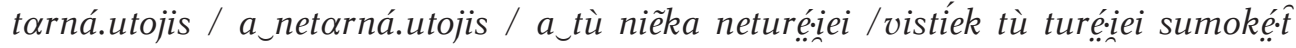

${ }_{19}$ A. Kaikarytès pastebejimu, ,priesagos $-(t)_{o j-}$ vediniai Joniškio šnektoje, tikètina, ir Žagarès, turi trejopą galūnę - /-as/, /-ịs/ ir /-ụs/“ (Kaikarytė 2010: 43). 
pazgídi.toji. nuvệ.ie.s (Žg). Matyt, yra vartota ir galūnė -us, bet tokiu pavyzdžiu įrašuose tik vienas - prašík mókki.tojeus / leĩ palé.ǐ̌ i._ú.ogas (Žg).

Irašuose aptiktas ir kažkada buvusios darios (M. Slančiausko bei jo pagalbininkų pasakojamojoje tautosakoje dažniau vartotos) vardažodinės ypatybės turètojo priesagos -uitis vedinys [tóks vaikũ.ĩtis neblókss (Žg)].

Kaip respondentai savitai pasirenka priesaginic daiktavardị, atspindi daiktavardis gyvulys, kuris žagariečių vartojamas ir kaip gyvuolys [nùdvẹse kogz gí.vuoli.s / nemèzdava i._duõbe. (Žg)], ir kaip gyvalys [gĩ.valem nepasakí.si/ tùrì

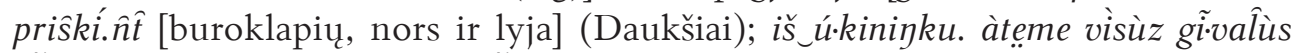
(Žiuriai); su gívaleís mẹ́gau (Žg)].

Daiktavardèti linkę pavieniai priesaginiai būdvardžiai ar įvardžiuotinès jų formos. Iš priesaginių, ypatybę nusakančiųjų, minètini sudaiktavardèję marginiukai ir vyriškas, pvz.: tòkié margin̂̀ukai bú.dava [sijonai] (Žg); ká.r̂vei reîk turệ̂t i_víriš̌ka. namũõse / o_mẽes neturé.jom (Žiuriai). Sudaiktavardèja įvardžiuotinès būdvardžiu ar įvardžiu formos, pvz.: svâ̂̉bx́.use / ka jeuníesiem dá.rba nẹ.

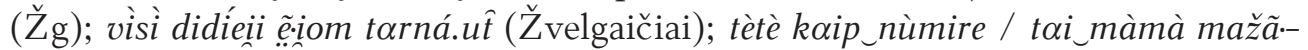
ses išmó.ke / tos_mã.žoses trî̀.s (Žg); i._*rí.ga. nuvažuõs / tai_suknẽ.le. nupĩ.r.rkus /

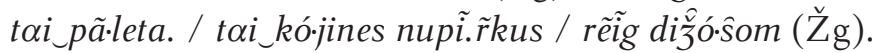

Žagarès šnektoje dūriniai sudaryti be jungiamojo balsio iš daiktavardžių

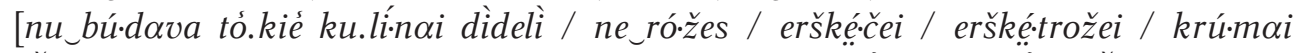
(Žg); kur_i._lèdjü.ri. palé.ide žmõnis / tai_té.n tìkroí bùva boísù (Žg)] arba iš daiktavardžio ir veiksmažodžio [nu_dàbà tos_ká.rtmetẹs / aš_nenó.ru tok̂un. (Žvelgaičiai); daúgæú samdí.dava lĩ.ñšluoti. [kas linus išminkština, paruošia] (Žvelgaičiai); pas_toz_gaspadìne(s) sếseri. / toi_tế. grínin skũ.r.lupei (Žg)]. Žodžiuose, kur susidaro sunkiai ištariamų priebalsių samplaika, dažniausiai įterpiamas jungiamasis balsis a, pvz.: jeigu ã.vi.s í.rà tubìnes / tó.kes juodburnes / juodgalves /

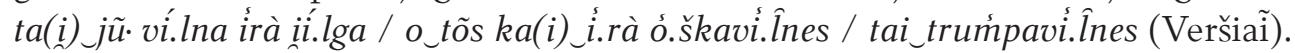

Būdvardžiai Žagarès šnektoje dažniau vartojami priesaginiai nei priešdèliniai. Priesaginiu -ingas, $-a$ iš būdvardžio baisus išryškinama stiprinamoji, pabrèžiamoji reikšmė ir siekiama vaizdo efektingumo, plg. baisí.ggi sklæ̀paí iš_móle // u_viŕšùzz bùva medínis // nu_i_pàdege (Žg).

Pastebèta priesagos -inis, $-\dot{e}$ vedinių iš pamatiniu žodžiu einančių daiktavardžių ar veiksmažodžių, nusakančių daikto išskirtinumą, vartojimas: bùva veịi-

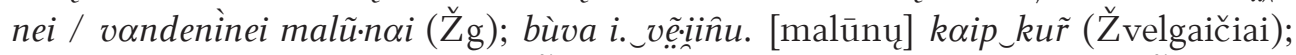

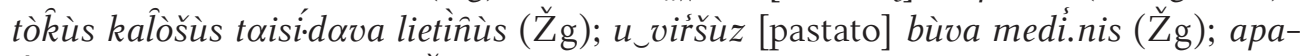
tìnei aũkšt $\alpha i$ bùva mú.ra (Žg). Panašumo ir būdingos ypatybès reikšmėmis vartojami būdvardžių -iškas vediniai iš daiktavardžių milžinas ir senove, pvz.: bùva mi. Ižiniški tvá.rtai akmenìnei (Žg); ižgadìna senóvviška. t(a.)_ansá.mb̂li. (Žg).

Ir daiktavardžių, ir būdvardžių mažybinès-maloninès formos sudaromos su priesaga -utis, pvz.: mažútis (Veršiai); čuplú.tis (Žvelgaičiai). 
Žagarès šnektoje, kaip ir rytų aukštaičių šnektose, vartojami priešdèlio po-/ pa- vediniai, žymintys ypatybès kiekį, pvz.: pàšvars vańduó (Žg); visì pó.jeuni / pàjeuni $(\check{\mathrm{Zg}})$.

Pastebėta, kad Žagarès šnektos ịrašuose vartojami kokybiniai būdvardžiai su galūne -us, pvz.: dí.rbom / liñksmu.s / smã.gu.s (Daukšiai); suñku.(s)*smetóna

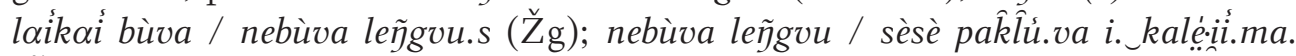
(Žg).

Būdvardžių dūriniai, kaip ir daiktavardžiu dūriniai, sudaromi be jungiamojo balsio, pvz., bú.dava tòks mẹli.nmã.rois muĩls (Žg).

Ypatybès kiekio skirtumams išryškinti Žagarès šnektoje vartojamas būdvardžių aukščiausiasis laipsnis, turintis galūnę -is, pvz.: sveikx́.usi(ž) žmó.gùs èsù (Daukšiai); sènæú bú.dava pú.sri.ti.(s) ŝtipróx.usis / piétaí ir̃gi / vakaríene / baltà

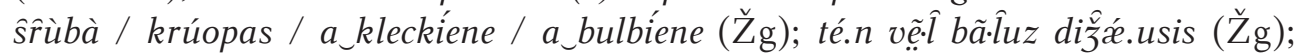

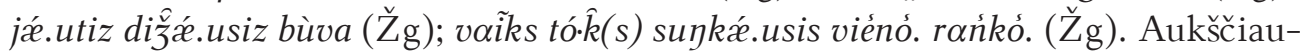
siasis laipsnis gali būti įvardžio pats ir įvardžiuotinès būdvardžio formos jun-

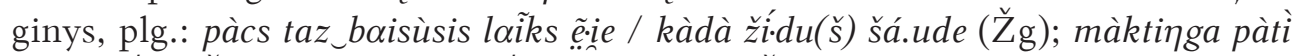
mažóji írà (Žg); toi_tà [sesuo] írà pàtì mažóji (Žiuriai).

Žagarès šnektoje plačiai vartojamos ịvardžiuotinès būdvardžio formos. Vienomis jų respondentai siekia ką išskirti pagal ypatybę, pvz.: brólis karúomenẹi bùva / tai_bùvaú taz_didĩ.siz dã.ribini.ks (Žg); i_mã. bùva blogàsis kãâsnis i_sunkkà-

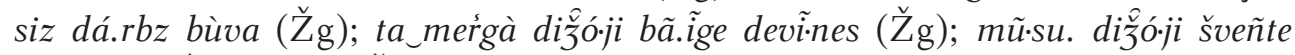

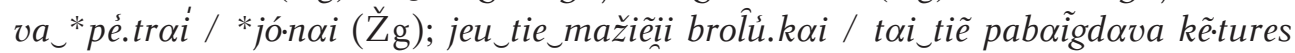
tas_klàsès (Žvelgaičiai); visì tiễjeu jeuniêje / pà-(a)ugle⿳亠丷厂 / jeu_pasễne. (Žiuriaĩ). Kitais atvejais įvardžiuotinès būdvardžių formos vartojamos nurodant rūšsi, amžių, pvz.: o_kitì turẹedava / nèžinaú / a_bá.ltoje glúoŝne / a_raudónnaje glúoŝne šakùte. tó.ke. nusipjóovi. / ir_eĩdava teĩp vá.ikščcodami và (Veršiaĩ); selen̂̀ukes í.rà smú.l̂koses / stam̃boses (Veršiai); nèžinaú kur̃ palika màna vi.reśńóóseś / sèsuó / pùsesere (Žg); da_vaíkùs mažúoŝus reiké.dava prižu.ré. $\cdot \hat{t}(\check{Z} g)$.

Respondentai linkę derinti būdvardị prie daiktavardžio, todèl būdvardžio linksnio galūnè gali būti nesisteminè, plg. pùsesere / tai_anà ar̃ iž_dideloś śeimó.z bùva $(\check{Z} g)$. Kartais, jei pasakodamas respondentas daro pauzę, derinimo gali ir nebūti, plg. bùva brañgu.z|dúona_ta $(\grave{Z} g)$.

Kiekiniai sudurtiniai skaitvardžiai Žagarès šnektoje sudaromi su sandu -leka, plg.: aštuonólleka [tūkstančių davè] / uštêk̂ŝme (Žg); já.unz da._bùva / sep̂ti.nóóleka mê.tu. (Žg). Diskurse pastebimas kiekinio skaitvardžio derinimas su daiktavardžio linksnio galūne [má.n dã.ve peñ́kùs litùs (Žg); tarná.udava čè šê̌s̀ùs mẹ.neŝus (Žg)] arba tokio derinimo, manytina dèl bendrinès kalbos įtakos, nèra [trì(š) šimtùz gá.unu / nu_kàs tàs írà (Žiuriaĩ)].

Kelintinių skaitvardžių įvardžiuotinės formos nėra dažnos, bet jos neretai atliepia sakinyje daiktavardị, t. y. žymi subjektą [o_tretĩ.sis / jeu_jé.m gẽ łaži:s / 
surakí.ntas rañkas (Žg)], arba atlieka atributinę funkciją, t. y. pavaduoja būd-

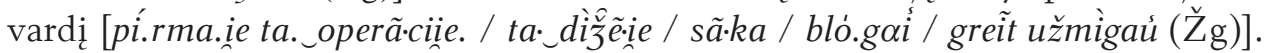

Žagariškiai tebevartoja dviskaitą. İrašuose pastebèta skaitvardžių dviskaitos akuzatyvo forma, plg. [pencijos] gá.unu dù šimitù septínezdé.šim (Žg). Dažniausios dviskaitos galininko formos su daugiskaitiniais daiktavardžiais metai, menesiai arba vienaskaitinèmis formomis litas, karas, pvz.: i.kabina jeu_šiñta. / devínezdê.šim $(d)$ dù mètù $(Z ̌ g)$; tètè bùva daũk senèsnis už_màmá. / par_dvìdešim(d)

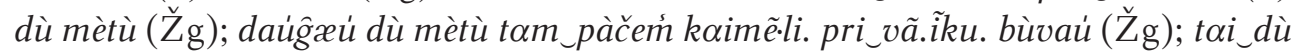
mẹ́neŝu mokìna $(\mathrm{Z} g)$; jeu_àž dù kàrù pá.rgi.venau $\left(\mathrm{Z̆g}_{\mathrm{g}}\right)$; dúodu dù lìtù por_mệ.nesi.

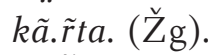

Šnektos įrašuose aptinkamas atskirų ịvardžių (ypač parodomojo tas, $t a$ ) dvejopas vartojimas: vienais atvejais minètas įvardis atlieka savo funkciją, kitais atvejais jis vartojamas kaip artikelis (artroidas), plg. i_teĩp ta_ži.dé.lka ižgé.lbeie ta. gi.víbe. $(\check{\mathrm{Z} g})^{20}$.

Žagarès šnektoje vartojama ịvardžių samplaikų. Pavyzdžiui, turèjimui, nuosavybei išreikšti sakoma dviejų ịvardžiu (asmeninio savybinio savas ir pabrèžiamojo pats) junginys, plg. mã.s turẹ́liom kèlès ká.r̂ve(s) sàva pàtiés (Veršiaĩ). Vietoj parodomojo tas, ta respondentas pavartojo daiktavardžio ir parodomojo ịvardžio pats su stiprinamąja dalelyte jau samplaiką, plg. o_i._viduri. stó.v̂ tas_mašins pàcs_jau (Veršiaĩ) ${ }^{21}$.

Žagarès šnektos tekstuose pastebèta parodomojo įvardžio anas, - $a$ įvardžiuotinè forma: anàsis / tàz ber̂nùks ( $\check{\mathrm{Z} g}$ ).

Joniškio šnektų, kurioms priklauso ir Žagarès šnekta, veiksmažodžiai yra kito kamieno ir asmenavimo paradigmos, plg.: jiẽ sée.ž / ir_àš aciséedau šàlè (Žg); tà(s)

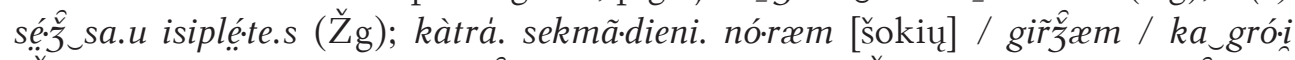

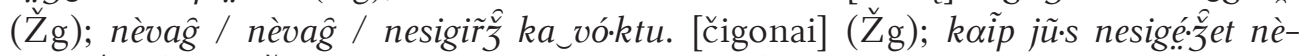

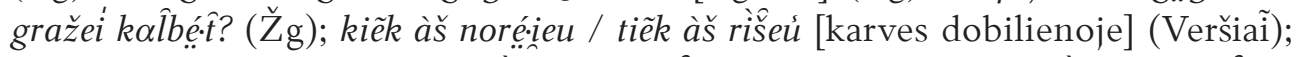
àš aúginaú / vaŕgaú / dàbà palîkset / išvažúoset / gaĩla màmàs palìka / acisàk̂xú kavalíereus ( $\mathrm{Z} g)$.

Kartais respondentams pasakojant prasprūsta gana netikètos veiksmažodžiu formos išsigasti, išsiganda, išsigando arba budetti, budejja, budejjo, pvz.: mojevines žolê.les nuo_ižgašče bùva / nu_va_kad_isigañdi / nu_va_teĩp / kad_už_nùgaró.s / sudúok par_nùgara. / isìga.stì (Žg); apré.ggi / dèdì i. grã.ba. / i_budé.ii (Žg).

Žagariškiai, kaip ir kaimynai žemaičiai, sangrąžos dalelytę nukelia į žodžio galą, pvz.: tù neklausíkis (Žg); vis_tíek nemã.tos / kur̃ añz dĩ.ñga [apie vyną] (Žg);

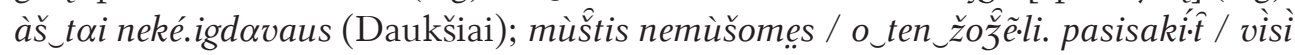

20 Apie artroidą plačiau žr. Rosinas 1988: 59-67.

${ }^{21}$ İvardžių samplaikos - stabilieji žodžių junginiai - numatomi plačiau aptarti rengiamame sintaksės skyriuje. 


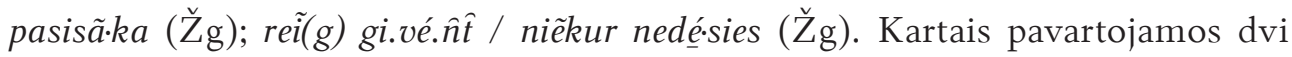
sangrąžos dalelytes - po priešdèlio prieš šakni ir žodžio gale, pvz.: apsivedas /

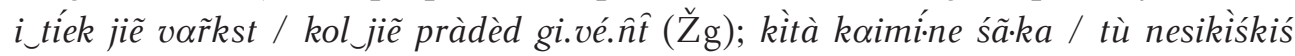

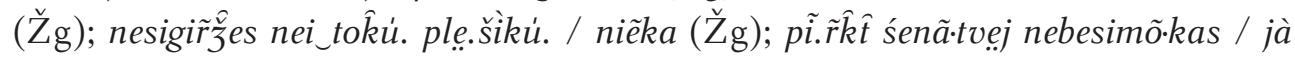
$(\check{Z} g)$.

Žagarès šnektoje dar pavartojamos senosios atematinio asmenavimo formos, pvz.: màmà paliêkt_jau ta.duonĩ.te. sukramtíta. su_sakarinù (Žiuriaĩ); nã.k̂ti. nemiẽgtu (Žg); užmiẽgti / tàdà pasí.lisi žmó.gùs / ir_àš tàdà užmiẽgtu (Žg); atró.da /

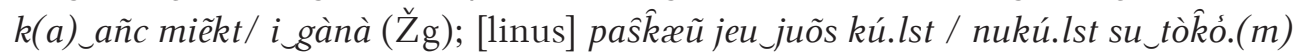
medìnẹm / nù_jæu šukú.oj (Žg).

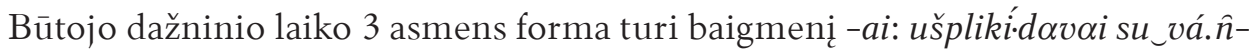

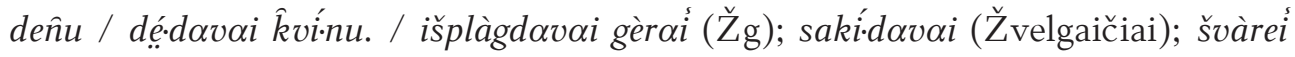

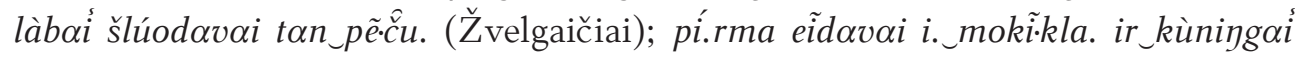
(Žg); tai_nèždovoi i._dá.rba. tàšès tòkè(ž) žmoni.m / vá.lloi.dova [obuolius] (Žg);

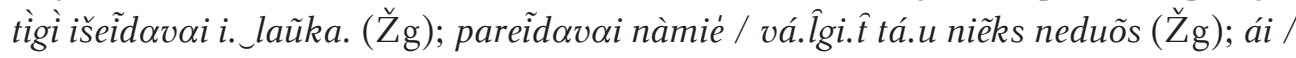
kaĩb gràžei šó.gdavai! (Žg) 22 .

Išlaikytos ir senosios veiksmažodžio būsimojo laiko daugiskaitos trečiojo asmens formos, aptinkamos kone visose lietuvių kalbos tarmèse, plg.: kà_jau

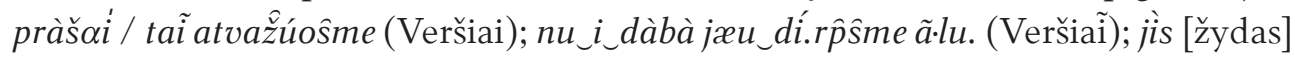
usirã.ša an_pópere / jì(ž) žina / ka_mã.s atidúoŝme tuos_pìnigus / kíek i.kainúoi /

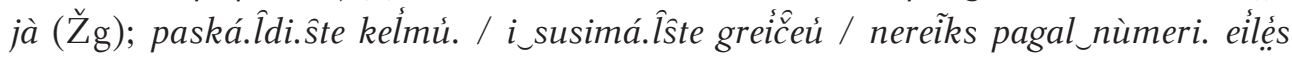
lá.uk̂t̂t tàdà (Veršiai); $\alpha_{\_}$jũ.s visadà tòkié bũ.śte / kad jũ.s neĩnat ni_i_bažnĩ.če.? (Žg);

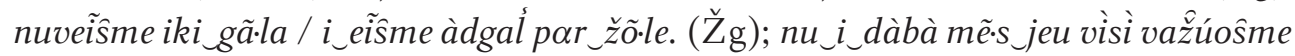
(Žg); o_ta._mé.ile. / vá.îkaí / ràŝte / i._tu._šé.ímú. pri-augí.nŝte / i._tu._víru. /

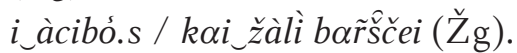

Žagarès šnektoje geidžiamąją nuosaką reiškia esamojo laiko trečiasis asmuo ir dalelytè lai (rečiau lei), pvz., laĩ iniñ ne-uždí.rba tiẽk / par_pùsmeti. jau jiñ pràktika(š) šiêk tiêk i.gìie (Veršiaî) ${ }^{23}$.

Irašuose iš Žagarès šnektos pastebimas veiksmažodžio bendraties trumpinimas, ypatybẻ būdinga ir kitoms lietuvių kalbos tarmėms, o bendraties kamiengalis dažnesnis su -yti nei -inti, pvz., jà / àvis augídavom / lìnus augí.dava / augídava kvínus (Veršiai).

Tranzityvusis priesaginis -uoti vedinys iš mëšlas žymi aktyvaus veiksmo nu-

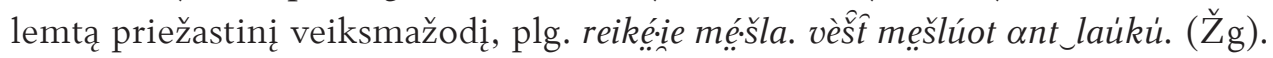

22 Apie jas plačiau žr. Grinaveckienè $\overline{1962}: \overline{147}-169$.

${ }^{23}$ Išsamiau apie šị reiškinị bus rašoma sintaksès skyriuje (straipsnis rengiamas). 
Savaiminis priesagos -telèti intranzityvusis veiksmažodis atitinka priešdèlinị paaugau, paūgèjau, pvz., dauĝxũ á.ukteléieu / jeu_pradệieu ant_mašina. dí.r̂́p̂t (Žiuriaĩ).

Priešdėliniais veiksmažodžiu vediniais Žagarès šnektoje itin subtiliai nusakomas patikslintas veiksmažodžiu reiškiamo veiksmo pobūdis. Priešdẻliniu ap-

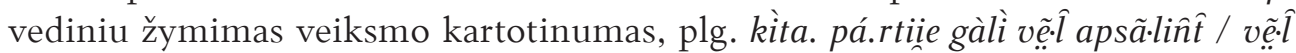
nutê.kin̂t (Veršiai). Vedinys su at- vartojamas to paties veiksmo atkartojimui (po kurio laiko) nusakyti ir sudaro pa-/at- santykinę dermę, plg. jiẽ visì po_víena. atrã.ša / o_má.n visiẽm atrašít. (Žg). Priešdèlinis at- vedinys sudarytų reikšminę dermę su už- vediniu, plg. karjèrus kaip_ǐškase / mùm jeu_niẽks nebepriklaũsa / nebe-atmó.k (Žvelgaičiai). Priešdèlinis ịdomautis ịgyia reikšmę 'domètis', pvz., kàs i.domã.vos / tai_tàs ir_šeñdie mók ta.dá.rba. dí.rp̂t / kã. màmà dí.rbdava / o_kàtràs ne-i.domã.vos / o_gál jám lã.îka nebùva / jis ir _šeñdien nežina /

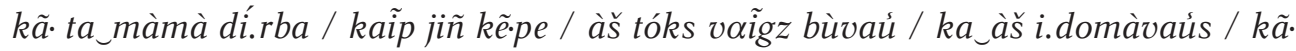

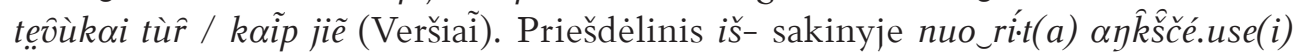
iškel tàvì $(Z ̌ g)$ atitinka $p a$ - vedinio reikšmę. Priešdèliniai veiksmažodiniai vediniai išryškina kalbančiojo akcentuojamų veiksmažodžių reikšminius niuansus. Kontaminacijos pavyzdys galètų būti toks: jiñ never̃pus / ir_ne-á.udus [nèra verpusi ir nèra audusi] (Veršiai).

Žagarès šnektoje itin dažni priešdèlio $n u$ - vediniai. Kartais tokie priešdèliniai vediniai atitinka priešdẻlinio su- vedinio reikšmę, plg. nùdege / pupí. $/$ užlígina ví.ska. / ižgadìna senóvviška. ta._ansá.mb̂li. (Žg); šví.lpi. paspá.ude / nùšvipe / ka_jau_dá.rbz baîkcs (Veršiai); tas_já.utiz bùva tíek nušá.udi.cs / bet_nenušá.ucs (Žg); pí.rtis nebùva nudẽ.gi.ta mũ.su. (Žg); šušá.ude nàmùs / kìtùs nudẽ.gina (Žg); tie_litaí jeu_dàbà làbaí nuprastéfie [menka prekinè vertė] (Žg). Nu-vediniai gali atliepti pri- vedinių reikšmę, plg.: [karvę] pardaũk nuriše.z bùvaí / par_tólli (Veršiai). Jie gali pavaduoti $p a$ - vedinius, plg.: dãa. žàdù i..* š̃úlùs nurašít. [laišką] (Žg); kiek àž dàbà nusìklausaú / àš pasipiktinus èsù (Žg). Kartais tokie vediniai atstoja kelių priešdèlinių vedinių reikšmę, pvz.: ap(i)-, iš-, pa-, su-, plg.: nupã-sakoje / kó.kes pã.sekmez gã̂l bú.ti (Žiuriai); ké.ls kai_eídova / tê. ĝ̣̂́.vei nùkastì $(\check{Z} g)$. $N u$ - vediniai gali atitikti per- vedinių reikšmę, plg. i_ta. bùta. nurã.še [vai-

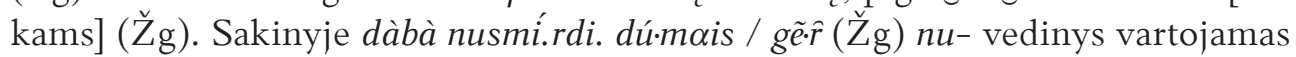
su- ar per- vedinių reikšmėmis.

Kaip subtiliai parenkamas priešdèlinis vedinys, rodytų ir sakinys su dviem $n u$-vediniais, kurių pirmasis atitiktų per-vedinị, o kitas būtų vartojamas tikrąja nu- reikšme, plg. tòki gràži bùva kumelùke / nušóve visàs kẽ.tures kó.jes var̂̂kšei / o gí.và / màmà da._prã.ša to. karẽ̃ive / nušá.ukit / kãa añs ká.ykinaz dàbà (Žg). Priešdèlinis $n u$-vartojamas veiksmo intensyvumui nusakyti: $u_{\_}$viřšsuz bùva medí.nis // nu_i_pàdege // nùdege (Žg); kìta. pá.rtiiie gàlì vệ.l apsã.lin̂t / vệ.l nutễ.kin̂t (Veršiai). Minèti priešdèliniai vediniai gali atitikti su- arba $p a-$ vedinių reikšmes, 
plg.: nùŝleg [obuolių sūrị] (Žg); taĩb dã.îlei nudã.ra [nugludina suformuotą duonos kepalą] (Žg). Sangrąžinè veiksmažodžio su priešdèliu $n u$ - forma reiškiamas veiksmo intensyvumas: [sūnus] tíeg bùva nusisĩ. roge.s / i_ta_dã.ktare bùva kaškur išvaž̃̃̃vus (Žg); òbuolú [vynas] / ka_nugi.vé.n / kai gĩ.ñtors (Žg). Nu- veiksmažodiniais vediniais nusakoma veiksmo trukmè: às vệl nukeñč u [kurị laiką patyli] (Žg) arba [vagys] televìzor̂u. spalvótta. ìšneše / dá.iktus nurĩ.ñka (Žg). Priešdèliniai $n u$ - vediniai vartojami vietoj kitu priešdèlinių (iš-, pa-, per-, pri-, su- ir pan.) veiksmažodžiu (žr. 2 diagramą).

2 Diagr AmA. Priešdèlinių $n u$ - veiksmažodžio vedinių atitikmenys

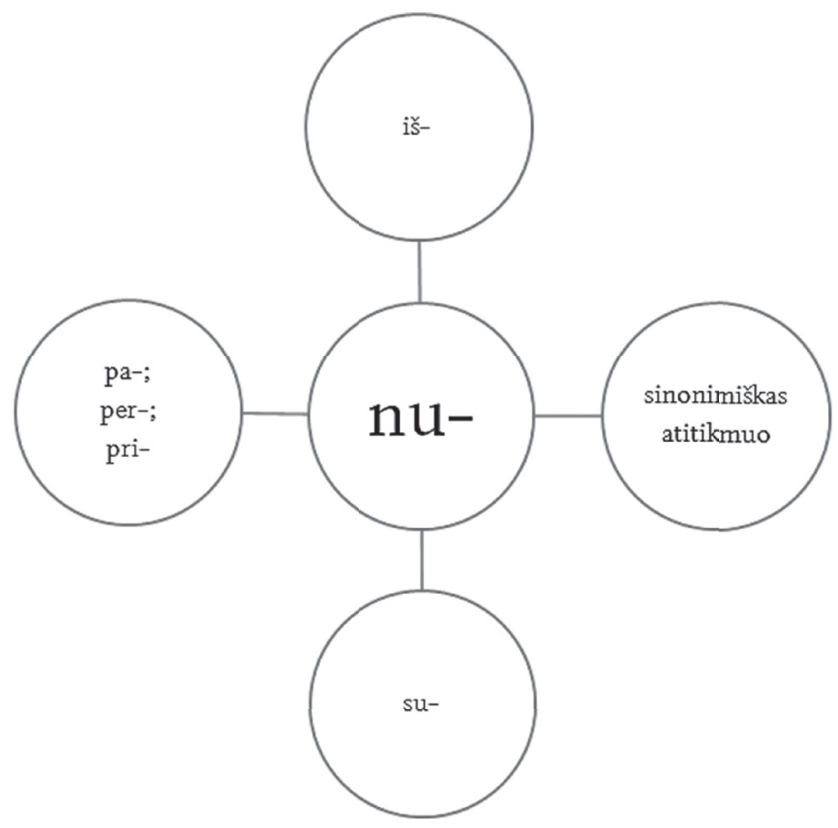

Priešdèlinis $p a$ - vedinys Žagarès šnektoje atitiktų veiksmažodinių iš- vedinių reikšmę, plg.: sušlã.pinam / ir_pã.tempæm an(t)_píevos [audeklą] (Daukšiai); àš / kad_i_víriškis / dúona. išmókkčeu kèp̂t / dã. pakèpčeu (Veršiaĩ).

Plačiai respondentų vartojamas par- kaip veiksmažodžio priešdèlis gali atliepti at-ir iš- priešdèlinių vedinių reikšmes, plg.: pí.rma. lá.iška. kat_nùrašeú / tai_pá.rŝunte pinigũ. (Žg); śu_víru parśiśkíre (

Priešdèlinius pri- veiksmažodinius vedinius žagariškiai vartoja mažybine reikšme vietoj už-, plg. biškê.li priplikí.dava tu. „mí.ltu. (Veršiaĩ). Sangrąžinès priešdèlio pri- veiksmažodžiu vedinių reikšmès veiksmo baigmei nusakyti atitiktu priešdèlinių nu-, pa-, su-, už- veiksmažodžių reikšmes, pvz.: p prisimiřša 
[pavardès] (Žg); aš_p̂risistebẹ́ieu ar̃ (Veršiaĩ); bañda. gàneú / prisilí.ga ká.rves mí.lŝŝt / i_ká.rves mí.lždavau (Žvelgaičiai). Intensyvesni veiksmą atspindi vedinys prisukti, reikšme 'prisemti': kùbilus vã.ñdene prrisùgdavom i(š)_šú.l̂ne (Žg). Perkeltinę reikšmę igyja prikinkyti - 'paskirti dirbti': dá.úĝxú prikiñ̂ke pri_ver̂́sê.lu. (̌̌g).

Vartojami ir su- priešdèlio vediniai, pvz., sangrąžinis subjekto atliekamas veiksmas susiubagauti reikšme 'prisirinkti, susirinkti': susi-ubagã.va tu. pìningú. dễš̀im tú.kstanču. (Daukšiai).

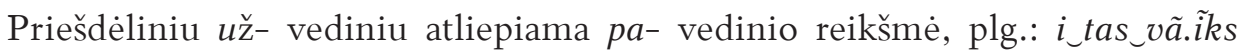

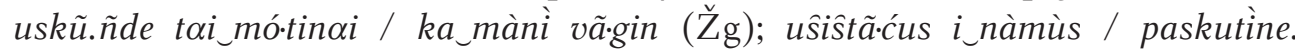
sveikã.ta. dẹ.ius i_da. mán reĩk išeî̃ iš_nàmú. (Žg). Sakinyje negá.l̂l uskũ.stis [maistu] (Žg) $u \check{z}$ - vedinys atliepia 'nusiskųsti' reikšmę. Kitu atveju $u \check{z}$ - vedinys atliepia iš- arba sinonimiško prižiūrèti žodžio reikšmę, plg. reikệ:ie tas_màmàs / ta.gi.-

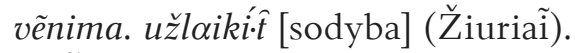

Žagarès šnektoje gausu dalyvinių formų. Veikiamosios rūšies esamojo laiko dalyviais nusakoma reikiamybès raiška, plg.: vìskas pẽ.r̂́kams / àš jau_nèbegalù

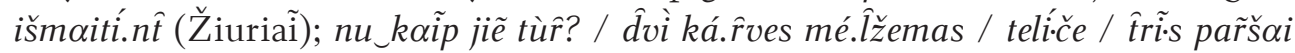
(Žiuriaĩ); tàs vìsas pã.grinds ta_bú.lve nèperkama i.rà (Žiuriaí). Kitais atvejais esamojo laiko dalyviu nusakomas galejimas atlikti veiksmą, plg.: bùva mašins piźx.unams (Žg); kèlei tiẽ ne-išvažzú.ojemi (Žg); *liétuvó.s laĩke bú.dava mũ.îla / kòke tik norệie / búddava i_drabùž̃u. skallbæma / ir_burnõ.z bùva (Žg). Būtojo laiko dalyviais nusakomi sudètiniai neveikiamosios rūšies laikai su būtojo kartinio laiko neveikiamuoju dalyviu, pvz.: i_nelé.ide lá.idot $\alpha n_{\smile}$ to. gìminẹ bùva lá.idota (Žg); duõbez bùva / kur_dú.rpes iškasta (Žg); màna mamíte $\tilde{i} \cdot k \tilde{x} \cdot p u s$ [duoną] / amžinã.tilis (Veršiai).

Atributinès reikšmès esamojo laiko dalyvis derinamas su daiktavardžiu panašiai kaip būdvardis, plg. ne-išvé.ygæmui kãarui rê.ĩg bú.ti (Žg).

Prieveiksmio funkciją Žagarès šnektoje dažnai atlieka sustabarejję (suprieveiksmėję) daiktavardžių linksniai, dažniausiai vietininkas, pvz.: pá.ŕrvaž̀̇̀aú nàmié (Žg); par̃vež nàmié / nú.kuli [linų galveles] (Daukšiai); gànæú àvìs / piétú. pareĩdavau nàmié (Žg); važúoju nàmié iš_tu. * *miknãåč̉u. išlé.idus piẽna. (Žg); kíek

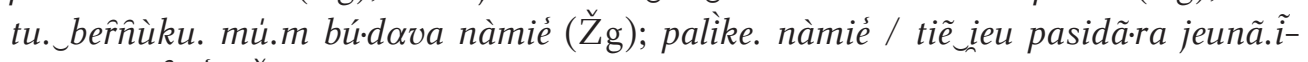
seis / pĩ. $\tilde{r}$ šleis (

Suprieveiksmèja ir kitų daiktavardžiu (pvz., kaimynai) vietininkas, plg.: čè /

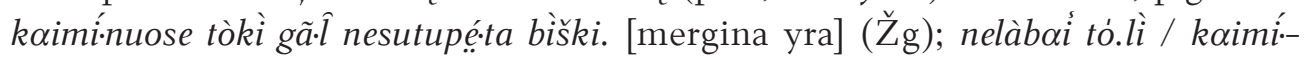

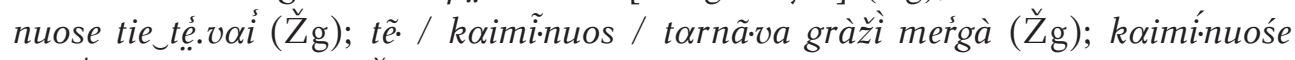
tòkei ži.dê.lei gi.vẽ.na (Žg). Neapibrèžtos vietos reikšme vartojami žodžiu joniškiečiai, žagariečiai vietininkai, plg.: té.n / joniškiê.čuoz / dã.ve keũle. (Žg); va_žagariễ̂́uos / *žagã rẹ gimusi (Žg). Suprieveiksmejjusiu vietininku nusakomas ir 


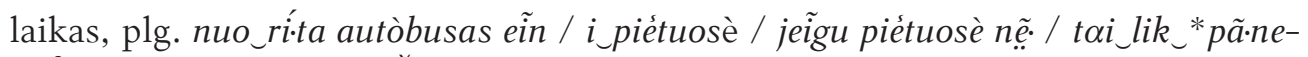
vẹže [tegali atvažiuoti] (Žg).

Žagarès šnektoje pabrěžiamąja reikšme vartojami būdiniai, sudaryti su prie-

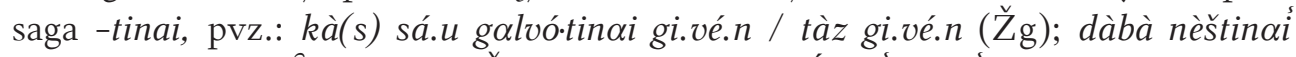

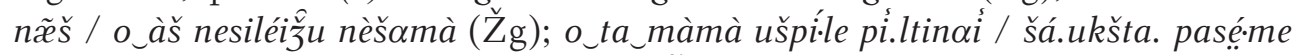

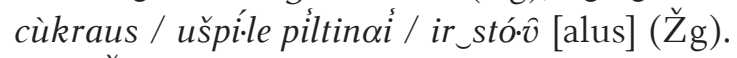

Iš Žagarès šnektos įrašų matyti, kad pastebèti morfologijos ir žodžių darybos polinkiai atspindi ir savitą, ir lietuvių kalbos tarmẻms būdingų kalbinių ypatybiuc atlieptí.

\section{ŽAGARĖS ŠNEKTOS LEKSIKA: ŽVALGOMASIS PJŪVIS}

Geriausiai tarmių, patarmių, šnektų ir pašnekčių leksiką atspindi tarminiai žodynai, bet kol Joniškio šnektų žodynas tebėra rankraštinis, tiksliau, parengtas pirminis kompiuterinis variantas, galima padaryti žvalgomąị eksperimentą. Autorè sumane iš Žagarès šnektos įrašų pasirinkti įvairesnès leksikos, atliepiančios savarankiškas kalbos dalis, ir palyginti, kaip ji atspindèta didžiajame Lietuviu kalbos žodyne, iš kurio bendrinè kalba semiasi žodžių, kuriame gausu pavyzdžiu iš tarmių, suprantama, turètų būti pavyzdžių iš Žagarès (Žg) arba Skaistgirio (Sk), Joniškio (Jnš). Žagarès šnektos įrašų pasirinktus žodžius galima vertinti publikavimo žodyne (vartojamumo bk), reikšmès naujumo, kalbų kontaktų ir kalbos vartotojo kūrybiškumo kriterijais. Pasirinkti apžvelgti per 80 žodžių, iš kurių 74 yra savarankiškos ir 9 - nesavarankiškos kalbos dalys.

Iš Žagarès šnektos įrašų pasirinkti aptarti 32 daiktavardžiai. Lyginta, ar šie daiktavardžiai ir jų reikšmès atspindètos Lietuvių kalbos žodyne iliustraciniais sakiniais ar nuorodomis. Minètame leidinyje nurodoma, kad Joniškio šnektose vartojami ciocè 'teta' (pvz. iš Jnš, Žg), dariniai 'dažai' (pvz. iš Jnš), gangis 'girnu įrengimas' (pvz. iš Jnš, Žg), manta 'turtas' (pvz. iš Jnš), obelys 'obuolys' (pvz. iš Jnš, Žg), patinginys 'kas nedarbštus' (nuoroda Žg), pode 'krikštamotë' (pvz. iš Sk ir nuoroda Jnš), ratinis 'verpimo ratelis' (nuoroda Jnš, Žg), skraistas 'prijuoste’' (pvz. iš Jnš ir nuoroda Žg). Taigi Žagarès šnektos ir Joniškio šnektu daiktavardžiu atspindys LKŽ sudarytu 29,03\%. Yra daiktavardžių, pateikiamų LKŽ be nuorodos apie tai, kad jie vartojami Žagarès šnektoje ar bent apie Joniškị, pvz.: čirškyne 'medinis barškalas, kleketas'; kaleda 'kunigui ar bažnyčios tarnams, apie Kalèdas apsilankantiems, duodama duoklẻ'; kirpšas 'kas trumpai nukirptais plaukais' (LKŽ pateikiamas žodis kirpšé, bet žinant, kaip svyruoja giminė Žagarès šnektoje, galima juos gretinti); lupatas 'sudèvèti, suplyšę drabužiai'; mergè 'samdinè'; prosmiltis 'priesmèlis, lengva žemè'; sèdyba 'sodyba'; 
sodžius 'kaimas'; sueiga 'giminių susiejjimas'. Apskaičiavus procentus, matyti, kad 37,5 \% daiktavardžių nenurodyti kaip vartojami Žagarès šnektoje (ir kitose Joniškio šnektose).

Visai kitomis reikšmėmis vartojami trys daiktavardžiai: $k a b \dot{e}$ 'plaukų segtukas' (LKŽ artimesnè būtų tik 'sagties' reikšmè); pūslys 'nedidelè mergaitė' (LKŽ yra tik 'mažas riebus kūdikis' reikšme, bet čia kalbama apie vaikščiojančią mergaitę); taškas 'vieta, kur perpardavinėjamas alkoholis'; trandis 'sutrūkusios ir pleiskanotos kojos' (LKŽ artimiausia reikšmè - 'kojos pado, kulno ar piršto tvinkinys'). Kitomis reikšmėmis Žagarès šnektoje vartojami 12,9 \% daiktavardžiu.

LKŽ visai nėra penkių Žagarès šnektoje vartojamų daiktavardžių, pvz.: aukotinis 'aukojimas, labdara'; drobnès 'vejaraupiai'; grižas 'kas susuktas, grị̌ztė'; liespienis 'pienas be grietinès, liesas pienas'. Vienas žodis - lingacija 'darželio gèlë' - leistų suvokti respondento kūrybiškumą: išvardijęs darželyje augančius augalus, baigia sakinį tarsi apibendrinamuoju žodžiu, nusakydamas ir kitas linguojančias gèles. Dar du žodžiai - palaidnieks 'pasileidèlis' ir palietis 'sulatvejęs lietuvis' - liudytų baltų tautų ir kalbų kontaktus. Pastarųjų daiktavardžių taip pat nèra LKŽ. Taigi 22,58 \% daiktavardžių nèra patekę i̇ LKŽ. Vadinasi, apie 35,5 \% žodžiu ar jų reikšmių savitumas galètų papildyti lietuvių kalbos atsargas, kalbos fondą.

Atskirai reikètų paminèti daiktavardžius, kurie, keičiantis gyvenimui ir nykstant atskiriems įrankiams (ar buvusiai technikai), yra pasitraukę iš aktyviosios vartosenos, bet respondentų prisimenami. Iš jų minètini aznyčia 'vieta, kur daiginamas ar džiovinamas salyklas' [aznî.če bú.dova teĩp / an_pirtiẽs lùbu. padaríta nu_tòki dệ:že (Daukšiai)]; branktas 'skersinis viržiams užkabinti, kinkant arkli'

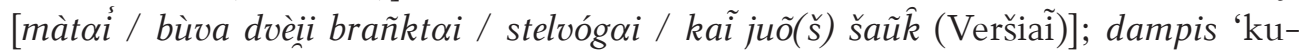
liamoji mašina' [tas_pẽ.čuz bú.dava dã.mpis / jà (Veršiaĩ)]; drangès 'vežimukas su mediniais ratais?' [nupjó.ve nuo_mẽ.ž̆e_va rìpkàs tókkes kê.tures / i_padã.re tó.kez drayĝùkes (Žiuriaĩ)]; grëbtis 'stambesnis šiaudagalys?' ir pelas 'smulkus šiau-

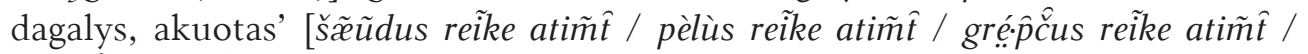

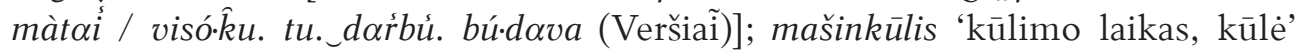
[par_mašin kulus [eidavo ị talkas] (Veršiaĩ)]; naginès 'iš vieno minkštesnio odos gabalo suraukta avalynè su apivarais' [sá.u nã.gines pàtì pasidarí.dovau (Daukšiai); žiẽma. tei(p)_pàt su_naginệ.lẹm dẹeẹeddovau (Daukšiai)]; tučkas 'čiulptukas, žindukas' [tùčka. iž_duoni.tes padarídava / i.dẹ́dava i._drobìni. lupatệlli. / jeigu *ulíte vẽ.r.rks / tai_tàdà tù dúok ta._tuč́kẽ.li. // padaríta. iž_duonítes ir_sakarina (Žiuriaĩ)]; žvangučiai 'diržas su skambaliukais, segamas arkliui po kaklu' ir pa-

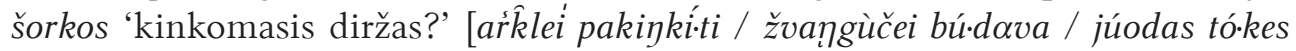
pašórkaz bú.dava (Veršiaĩ); á.rk̂li. kur̃ uškiñna / júodas / šikšnìnes / pašórkaz

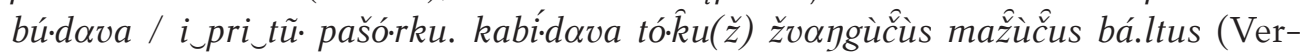
šiaĩ)]. Vieni žodžiai, kaip mašinkūlis (LKŽ mašinkūle)), nurodyti esant apie Žg, 
kiti - tučkas ir žvangučiai (LKŽ žvanguliai) - žinomi iš tautosakos (M. Slančiausko) ar M. Katiliškio raštų (grožinių kūrinių). Prie daugumos žodžiu nėra nuorodos apie vartojimą apie Žagarę ar Skaistgirị, Joniškį. Iš 11 pateiktų žodžių tik prie 3 LKŽ nurodyta, kad jie vartojami Joniškio šnektose, o prie 8 tokių pažymų nėra arba nėra net tokio žodžio LKŽ (drangès, grébtis, pašorkos) (žr. 1 lentelę).

I akis kritę Žagarès šnektos įrašuose vartojami būdvardžiai ar būdvardišką reikšmę iggyjantys įvardžiai, kurių susidare 13 , respondentų labai taikliai pasirinkti ir įtaigiai apibūdina daiktą ar reiškinị, arba sudaro stabilųị žodžių junginį. Vieni jų, kaip aukštynelkas 'gulintis ant nugaros' ir vijinis 'liktarnos rūšis', nèra patekę i LKŽ, o kiti, kaip katras 'kiekvienas' ir švakas 'silpnas', yra LKŽ su pateiktais pavyzdžiais iš Žg. Daugiausia tų būdvardžių, prie kurių nenurodyta, kad jie vartojami Žagarès šnektoje (ar Joniškio šnektose), yra: didysis karas 'pirmasis pasaulinis karas'; grynas 'tuščias'; maktingas 'šaunus'; mažas 'mažažemis'; šarpus 'darbštus'; vienišas žodis 'keiksmas, kalba su keiksmažodžiais'. Visai kita reikšme vartojami būdvardžiai gyvas 'rūgstantis, rūgstąs'; jaukus 'ramus ir šiltas'. Taigi 61,5 \% būdvardžių Žagarès šnektoje vartojami savitai (žr. 2 lentelę).

Pasirinkti aptarti 30 veiksmažodžių (ir prieveiksmių). Visi 19 veiksmažodžių yra LKŽ bazėje. Tik vieni jų vartojami kitomis (nei LKŽ) reikšmėmis, pvz.: bliauti 'atsikalbinèti' ir 'garsiai šaukiant kviesti'; išbraižyti 'išskutinèti peiliuku (margučius)'; išsiblaiveti 'nukristi putoms'; kvarksèti 'šnekèti'; minkyti 'ritmiškai kelti kojas'; nusitverti 'kartu gyventi'; spardytis 'gerai gyventi'; stoksoti 'būti nereikalingam, stovèti'; susitverti 'gimti'; važiuoti 'būti pašautam į krosnį'. Kitų veiksmažodžių reikšmés sutampa su LKŽ išskirtomis reikšmėmis, bet nuorodos, kad jie vartojami Žagarès šnektoje ar apie Jnš, nèra paminèta, pvz.: išvartoti 'išleisti už vyro'; nudilęs 'nebeprisimenamas'; nuūžti 'skubiai nueiti'; praprusęs 'pasimokęs'; parsikviesti 'parsivadinti gyventi, ikkalbèti sugrižti'; suderèti 'sulygti, sutarti dèl ko'; sušiauštas 'nelygaus paviršiaus'; šaukti 'vadinti'. Kiek kitoks 11 prieveiksmių vaizdas - į LKŽ nepateko formos atgaliau 'atgal' ir prietariškai 'tikint burtais'. Visai kitomis reikšmèmis vartojami juodai 'labai, patikliai' ir laisvai 'neapgaubtai stiklu, neįstiklintai'. LKŽ nèra nurodyta, kad prieveiksmiai plačiai 'išsiskirsčius po pasauli ar Lietuvą' ir 'turtingiau, prabangiau'; laisvai 'neapgaubtai (stiklu)'; prastai 'silpnai'; tikybiškai 'religiškai' ir skaudžiai 'šiurkščiai' yra vartojami ir Žagarès šnektoje. Tik prie ropa 'ropomis' ir valioj 'atdarai, atidarytos' LKŽ yra pavyzdžiu iš Joniškio, bet ne iš Žagarès. Nors, kaip susidaro ìspūdis, veiksmažodis (iš dalies ir prieveiksmis) gerai atspindètas LKŽ, bet kai kurios jų reikšmès yra būdingos tik žagariškiams (žr. 3 lentelę).

Žagarès šnektos įrašuose akis patrauke 11 nesavarankiškuc kalbos dalių. Ištiktukais ir dalelytemis respondentai siekè santūraus pasakojimo spalvingumo. LKŽ nèra nurodyta, kad ekspresyviosios kalbos dalys, tokios kaip: ar 'taip 
pat'; musènt 'turbūt, gal'; musint 'gal'; pliumpt 'kritimui ị vandeni nusakyti'; pur 'burzgimui imituoti', vartojamos ir Žagarès šnektoje. Kitos, pvz.: gan 'daug, pakankamai'; nemmaž 'visai'; makt 'kyšt', nurodytos kaip žagariškių vartojamos. Tik džing 'skleidžiamam garsui imituoti' LKŽ nėra, o artimos reikšmės žodžiai $d z ̌ i n g t$ ir džingu vartojami kitomis reikšmėmis (žr. 4 lentelę).

Pasižvalgymas po Žagarès šnektos leksiką dar labiau sustiprina mintį, kad tarmių, šnektų, šnektų grupių žodynai yra neišmatuojamas ir neišsemiamas lietuviu kalbos gyvasties lobynas.

\section{ŽAGARĖS ŠNEKTA XX A. PABAIGOJE: APIBENDRINAMOSIOS MINTYS}

Aptarti Žagarès šnektos įrašų, darytų 1998-2003 m., akcentuacijos ir tarminiai gramatiniai polinkiai vestu prie tiriamųjų XXI a. darbų, stebint šnektos kaitos polinkius. Akcentuacijos požiūriu Žagarès šnektoje vyrauja visuotinis kirčio atitraukimas. Kalbininkų pastebėtos mišriųjų dvigarsių kirčiavimo ypatybės vertos detalesnio tyrimo ir korekcijos, atsižvelgiant i pateikèjo tautinę priklausomybę ir kalbinę savivoką. Kisti turètų tam tikros fonetinès ypatybės, iš kurių minètina balsių $a, e, i, u$ ir priebalsių $c h, f, h$ tarimas; pridètiniu $j, v$ vartojimas; įdomu pasekti šlekiavimo ir priebalsių minkštinimo / kietinimo raidą.

Žagarès šnektos morfologinès ypatybès - skirtingi vardažodžių kamienai, skaičiaus ir giminès svyravimai, dviskaitos vartojimas, vardažodžio formų (ịvardžiuotinių, laipsnio, sangrąžos) savitas (ar skolintas iš artimų šnektų) sudarymas, veiksmažodžio kamienų ir formų vartojimo ypatybès - taip pat turètų pasiduoti kalbinei raidai.

Tarminiai įrašai leidžia susidaryti vaizdą, kaip Žagarès šnektoje sudaromi žodžiai. Respondentai dažniausiai vartojo priesaginius, priešdèlinius vedinius ir dūrinius. Pastebèta, kad priesaginiai daiktavardžiai sudaromi su priesagomis -atis, -ëjas, -elis, -ietis, -tojas, -uitis. O būdvardžiams dažnesnès priesagos -ingas, -inis, -utis. Žagarès šnektoje vyrauja priešdèline veiksmažodžių daryba, iš kurių minètini priešdèliai $a p-, n u-, p a-, p a r-, p r i-$ ir kt. Dūrinius žagariškiai dažniausiai vartoja be jungiamojo balsio.

Žagarès šnektos leksikos pjūvio apžvalga leidžia susidaryti vaizdą apie šnektoje savitai vartojamą leksiką. Respondentų subtiliai parenkamas žodis ar jo forma pasakojamiems vaizdiniams ar reiškiniams apibūdinti atspindi prigimtinès kalbos lankstumą ir tinkamumą dabarties mintims išreikšti. Kalbinė aplinka (šiuo atveju - Žagarès šnektos įrašai) rodo, kaip respondentas formuoja ir perteikia kalba savo kūrybinius sumanymus. 
Fonetinės ir morfologinès Žagarès šnektos ypatybės

(XX a. pabaiga - XXI a. pradžia)

\section{LIT ER AT ÜR A}

Bartkutè Nerija 2008: Joniškio rajono teritorijos toponimija: daryba ir raidos polinkiai. Daktaro disertacija. Šiauliai.

Daujotytè Viktorija 1998: Tekstas ir kūrinys. Vilnius: Kultūra.

Garšva Kazimieras 2005: Lietuvių kalbos paribio šnektos (fonologija). Vilnius: Lietuvių kalbos institutas.

Girdenis Aleksas, Juozas Pabrèža 1978: Nauji šlekiavimo stebejjimai Žagarès apylinkèse. - Baltistica 14(2), 127-129.

Girdenis Aleksas, Genovaitė Kačiuškienè 2000: Paraleliniai reiškiniai latvių ir šiaurinių lietuvių veiksmažodžio sistemose. - Kalbotyra 37(1), 21-27 [= Girdenis Aleksas 2000: Kalbotyros darbai 2. Vilnius: Mokslo ir enciklopedijų leidybos institutas, 307-314].

Girdenis Aleksas, Juozas Pabrèža 2000: Nauji šlekiavimo stebejjimai Žagarès apylinkèse. - Baltistica 14(2), 127 it. [= Girdenis Aleksas 2000: Kalbotyros darbai. Vilnius: Mokslo ir enciklopedijų leidybos institutas, 117-120].

Girdenis Aleksas, Juozas Pabrèža 2003: Sargiųiu ir žvarbiųjų priebalsių svyravimai XX a. pradžios žagariečio tekstuose. - Baltistica 37(2), 229-232.

Grinaveckienè Elena 1962: Kai kurios lietuvių kalbos tarmių ypatybès (iš 1961 metų dialektologinių ekspedicijų). - Lietuvių kalbotyros klausimai 5, 147-169.

Jonaitytè Aldona 1967: Latvių kalbos poveikis palatvès vakarų aukštaičių šnektų gramatinei sandarai. - Lietuvių kalbotyros klausimai 9, 171-182.

Jonaitytė Aldona 1960: Nauji duomenys apie Skaistgirio tarmès konsonantizmą. Lietuvių kalbotyros klausimai 3, 79-86.

Jonaitytè Aldona 1972: Palatvès vakarų aukštaičių nedėsningos fonetikos žodžiai ir jų kilmè. - Lietuvių kalbotyros klausimai 13, 31-41.

Jonaitytė Aldona 1969: Palatvès vakarų aukštaičių šnektų būdvardis, skaitvardis, įvardis. - Lietuviu kalbotyros klausimai 11, 183-221.

Jšpt 2001 - Joniškio šnektų pratimai ir tekstai, ats. red. J. Švambarytė. Šiauliai: J. K. Vasiliausko įmonè.

Kaikarytè Aušra 2015: Skaistgirio šnektos ypatybès. - Kalbos istorijos ir dialektologijos problemos 3, 150-173.

Kaikarytė Aušra 2010: Joniškio šnektos daiktavardžio linksniavimo sistema. Daktaro disertacija. Vilnius. 
Kardelis Vytautas 2008: Dèl junginių *1ē, *rē, *sē Mielagènų areale. - Baltistica XLIII(3), 485-494.

Kardelis Vytautas 2002: Dẻl galinių le junginių raidos šiaurès rytų vilniškių šnektose. - Baltistica XXXVII(2), 215-222.

Kardelis Vytautas 2002: Dèl junginių la, lė raidos šiaurès rytų vilniškių šnektose. Baltistica XXXVII(1), 107-114.

Liparte Evija 2000: Iliatyvo resp. prieveiksmio laukan reikšmės ir galimi sinonimai lietuvių kalbos tarmèse. - Lietuvių kalbotyros klausimai 43, 144-152.

Liparte Evija 2000: La. nost vs. malā vs. zemē un lie. žemèn vs. šalin semantiskās attiecības literārajā valodā un izloksnēs. - Linguistica Lettica 8, 151-179.

LKG I 1965 - Lietuviu kalbos gramatika 1. Fonetika ir morfologija, red. K. Ulvydas. Vilnius: Mintis.

LKG II 1971 - Lietuvių kalbos gramatika 2. Morfologija, red. K. Ulvydas. Vilnius: Mintis. Lkt 1970 - Lietuvių kalbos tarmès. Vilnius: Mintis.

Lktch 2004 - Lietuviu kalbos tarmiu chrestomatija, sudarè R. Bacevičiūtè, A. Ivanauskienè, A. Leskauskaitè, E. Trumpa, moks. red. L. Grumadienė. Vilnius: LKI.

Pabrèža Juozas 1998b: Žagarès šnektos fonetinės ypatybės. - Žagaré. Vilnius: Versmè, 781-787.

Pabrèža Juozas 1998a: Ar besama šlekiavimo pėdsakų Žagarès šnektoje? - Tarmés: tyrimas ir perspektyva (pranešimų tezès). Šiauliai: Šiaulių universiteto leidykla, 25-27.

Rosinas Albertas 1998: Baltų kalbų įvardžiai. Vilnius: Mokslas.

Švambarytė Janina 2001: Šiaurès Lietuvos paribio šnektų ištiktukai: struktūra ir reikšmè. - Linguistica Lettica 9, 73-84.

Švambarytė-Valužienè Janina 2018: Žagarès šnektos ribos. - Acta Linguistica Lithuanica LXXVIII, 135-148.

Urnèžiūtè Rita 1999: Tolimosios asimiliacijos reiškiniai Rudiškių (Joniškio raj.) šnektoje. - Tarmès: jaunujų kalbininku darbai (pranešimų tezès). Šiauliai: Šiaulių universiteto leidykla, 21-23.

Zinkevičius Zigmas 1966: Lietuvių dialektologija. Vilnius: Mintis.

\section{SANTRUMPOS:}

Jnš - Joniškis

KrŽ - Katiliškio raštų žodynas 
Fonetinės ir morfologinès Žagarès šnektos ypatybės

(XX a. pabaiga - XXI a. pradžia)

LKG I - Lietuviu kalbos gramatika, t. 1. Fonetika ir morfologija

LKG II - Lietuviu kalbos gramatika, t. 2. Morfologija

Lkt - Lietuviu kalbos tarmes

Lktch - Lietuviu kalbos tarmiu chrestomatija

Sk - Skaistgirys

Sln - Mato Slančiausko ir jo pagalbininkų pasakojamosios tautosakos rinkinių leksika. Žodynas

vaš - vakarų aukštaičiai šiauliškiai

Žg - Žagarè

\section{PRIEDA I}

1 LENTELĖ. Žagarès šnektos daiktavardžiai

\begin{tabular}{|c|c|c|c|}
\hline Žodis & Reikšmè & Iliustracija & $\begin{array}{l}\text { Yra / nèra LKŽ ir } \\
\text { LKŽ(e). Reikšmè }\end{array}$ \\
\hline abrè & $\begin{array}{l}\text { duonos } \\
\text { rūšis? }\end{array}$ & âbre vadìnos tòkì dúona $\left(\mathrm{Žg}_{\mathrm{g}}\right)$ & $\begin{array}{l}\text { 1. Didelė gelda duonai } \\
\text { maišyti. } \\
\text { Nuoroda Žg. Sakiniai } \\
\text { tik iš Jnš. }\end{array}$ \\
\hline aukotinis & labdara & 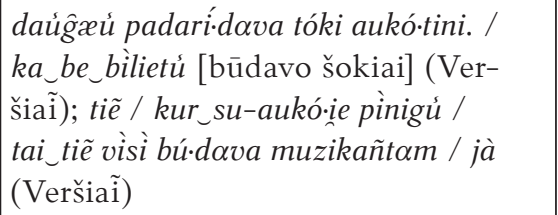 & LKŽ nėra \\
\hline ciocè & teta & $\begin{array}{l}\text { šaũkẹm *juliiãana / còce / ta_màna } \\
\text { pó·de (Žg) }\end{array}$ & $\begin{array}{l}\text { Ciocė 1. Teta. } \\
\text { Pavyzd žių iš Žg ar Jnš } \\
\text { néra. }\end{array}$ \\
\hline čirškynė & $\begin{array}{l}\text { medinis } \\
\text { barškalas, } \\
\text { kleketas }\end{array}$ & 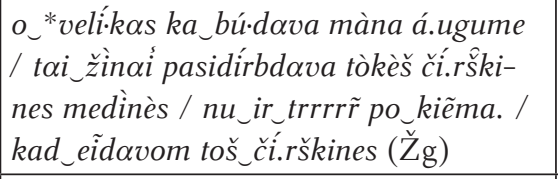 & $\begin{array}{l}\text { 1. Medinis barškalas, } \\
\text { kleketas, klekučiai. } \\
\text { Pavyzdžių iš Žg ar Jnš } \\
\text { néra. }\end{array}$ \\
\hline dariniai & dažai & 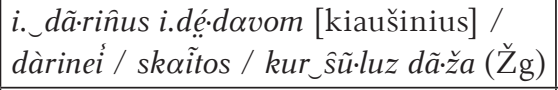 & $\begin{array}{l}\text { 1. Dažai. } \\
\text { Pavyzdys iš Jnš. }\end{array}$ \\
\hline drobnès & vèjaraupiai & 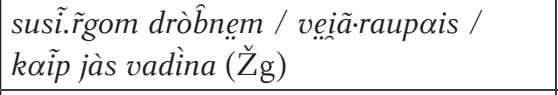 & LKŽ nėra. \\
\hline gangis & $\begin{array}{l}\text { girnų irren- } \\
\text { gimas }\end{array}$ & $\begin{array}{l}\text { kèturì gañgei má.ldava gi.vulǽ.m (Ver- } \\
\text { šiaĩ) }\end{array}$ & $\begin{array}{l}\text { 2. Vienerių girnų } \\
\text { ịrengimas. } \\
\text { Pavyzdys iš Jnš ir Žg. }\end{array}$ \\
\hline
\end{tabular}


JANINA ŠVAMBARYTE்-VALUŽIENE்

\begin{tabular}{|c|c|c|c|}
\hline Žodis & Reikšmė & Iliustracija & $\begin{array}{l}\text { Yra / nėra LKŽ ir } \\
\text { LKŽ(e). Reikšmė }\end{array}$ \\
\hline grižas & $\begin{array}{l}\text { kas susuk- } \\
\text { tas }\end{array}$ & 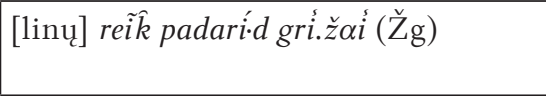 & LKŽ nėra. \\
\hline kabè & $\begin{array}{l}\text { segtukai } \\
\text { plaukams }\end{array}$ & $\begin{array}{l}\text { plá.uku(s) supíne / su_kãabem sùsege } \\
(\check{Z ̆ g})\end{array}$ & $\begin{array}{l}\text { Tokios reikšmės nėra, } \\
\text { yra sagties reikšmė. }\end{array}$ \\
\hline kalèda & $\begin{array}{l}\text { duoklè } \\
\text { bažnyčiai }\end{array}$ & 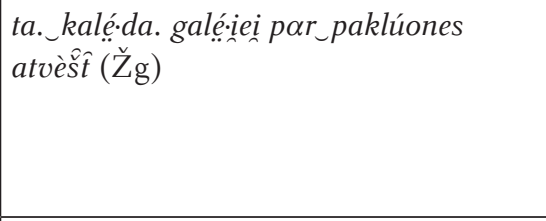 & $\begin{array}{l}\text { 3. Kunigui ar bažny- } \\
\text { čios tarnams, apie Ka- } \\
\text { lèdas apsilankantiems, } \\
\text { duodama duoklè. } \\
\text { Pavyzdžių iš Žg nėra. }\end{array}$ \\
\hline kirpšas & $\begin{array}{l}\text { kas nedai- } \\
\text { liai apkirp- } \\
\text { tas, trum- } \\
\text { paplaukis }\end{array}$ & $\begin{array}{l}\text { tòk̂́. kir̃pšu. nèmačæú / kai_màna } \\
\text { dùktẹ. [trumpai kirpti plaukai](Žg) }\end{array}$ & $\begin{array}{l}\text { Kas su trumpai nu- } \\
\text { kirptais plaukais, bet } \\
\text { žodis kirpšé. } \\
\text { Reikšmė nefiksuota } \\
\text { apie Žg. }\end{array}$ \\
\hline liespienis & $\begin{array}{l}\text { liesas pie- } \\
\text { nas, pienas } \\
\text { be grieti- } \\
\text { nès }\end{array}$ & $\begin{array}{l}\text { jìs negá.î tòke piẽna / liêspiene [gerti] } \\
(\grave{Z} \mathrm{~g})\end{array}$ & LKŽ nėra. \\
\hline lingacija & $\begin{array}{l}\text { darželio } \\
\text { gèlè }\end{array}$ & $\begin{array}{l}\text { bùva nastùrkas / sereñti.s / dauĝxũ } \\
\text { lingã.ciìes tó.kes (Žg) }\end{array}$ & LKŽ nėra. \\
\hline lupatas & skuduras & $\begin{array}{l}\text { [tėvas] } \alpha \tilde{n}(s) \text { supĩ. rgdova sènùs lùpatus } \\
\text { / ó.das (Žvelgaičiai) }\end{array}$ & $\begin{array}{l}\text { 1. Ppr. Pl. sudèvėti, } \\
\text { suplyšę drabužiai. } \\
\text { Pavyzdžių iš Žg nėra. }\end{array}$ \\
\hline manta & turtas & $\begin{array}{l}\text { išveže žmó·nis / àtẹme má.ntas / } \\
\text { i._kolkòzus tas_má.nta(s) sùveže / jà } \\
(\text { Žg) }\end{array}$ & $\begin{array}{l}\text { 1. Manta - turtas. } \\
\text { Nurodytas tik Jnš. }\end{array}$ \\
\hline mergè & samdinè & $\begin{array}{l}\text { àš par_merge. màžá tã.r̃navau (Žvel- } \\
\text { gaičiai) }\end{array}$ & $\begin{array}{l}\text { 2. Psn. ūkininko, buo- } \\
\text { žès samdoma mergina } \\
\text { darbininkè, samdinè, } \\
\text { tarnaitè. } \\
\text { Nenurodyta, kad var- } \\
\text { tojamas Žg. } \\
\end{array}$ \\
\hline obelys & obuolys & 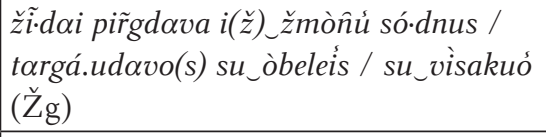 & $\begin{array}{l}\text { 1. Obelies vaisius. } \\
\text { Pavyzdžiai iš Jnš ir Žg. }\end{array}$ \\
\hline palaidnieks & pasileidèlis & àns nẹ. kòks pàlaidnieks / $a_{\_}$kã. (Žg) & LKŽ nèra. \\
\hline
\end{tabular}


Fonetinès ir morfologinès Žagarès šnektos ypatybès

(XX a. pabaiga - XXI a. pradžia)

\begin{tabular}{|c|c|c|c|}
\hline Žodis & Reikšmè & Iliustracija & $\begin{array}{l}\text { Yra / nẻra LKŽ ir } \\
\text { LKŽ(e). Reikšmé }\end{array}$ \\
\hline palietis & $\begin{array}{l}\text { sulatvèięs } \\
\text { lietuvis } \\
\text { (ppr. likęs } \\
\text { gyventi } \\
\text { Latvijoje) } \\
\end{array}$ & 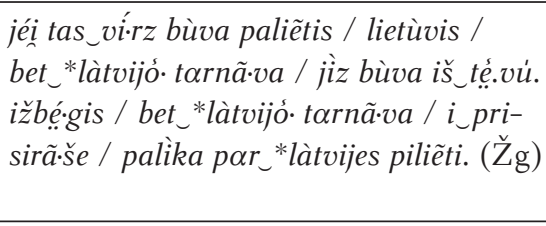 & LKŽ nèra. \\
\hline $\begin{array}{l}\text { patinginys } \\
\text { ar -is }\end{array}$ & nedarbštus & 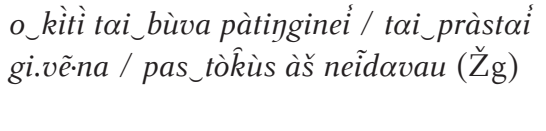 & $\begin{array}{l}\text { Tingokas, apytingis } \\
\text { žmogus. } \\
\text { Nuoroda Žg. }\end{array}$ \\
\hline podè & $\begin{array}{l}\text { krikšta- } \\
\text { moté }\end{array}$ & $\begin{array}{l}\text { pas_pó·de / sàkaú / bùvaú (Žg); } \\
\text { šaũkẹm *juliiãana / còce / ta_màna } \\
\text { pó.de }(\text { Žg) }\end{array}$ & $\begin{array}{l}\text { 1. Krikštamotè. } \\
\text { Nuoroda Jnš, o pavyz- } \\
\text { dys iš Sk. }\end{array}$ \\
\hline prosmiltis & $\begin{array}{l}\text { lengva } \\
\text { žemé }\end{array}$ & $\begin{array}{l}\text { té.n gèrà žẽeme / prõ.smiltis / nep̂rìgể } \\
\text { niêks (Žg) }\end{array}$ & $\begin{array}{l}\text { Smiltinga žemè, pries- } \\
\text { mèlis. } \\
\text { Nėra pvz. iš Žg ar Jnš. }\end{array}$ \\
\hline pūslys & $\begin{array}{l}\text { maža mer- } \\
\text { gaitė }\end{array}$ & $i_{\_}$pasitá.ikau àš / toks_pũ.ŝlis i.eît (Žg) & $\begin{array}{l}\text { 3. Mažas riebus kū- } \\
\text { dikis. } \\
\text { Pavyzdžių iš Žg ar } \\
\text { Inš nėra. Nesutampa } \\
\text { reikšmės. } \\
\end{array}$ \\
\hline ratinis & $\begin{array}{l}\text { verpimo } \\
\text { ratelis }\end{array}$ & 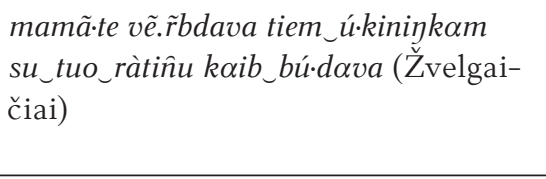 & $\begin{array}{l}\text { Ratelis, naminis ver- } \\
\text { pimo prietaisas. } \\
1 \text { ratinis. Nuoroda Žg, } \\
\text { Inš. } \\
\end{array}$ \\
\hline sèdyba & sodyba & sẹdíbo. ká.rves írà (Žiuriai) & $\begin{array}{l}\text { 1. Žemė apie namus su } \\
\text { visais trobesiais } \\
\text { Pavyzdžių iš Žg ar Jnš } \\
\text { nėra. }\end{array}$ \\
\hline skraistas & sterblè & 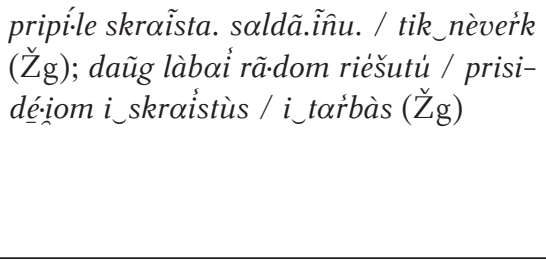 & $\begin{array}{l}\text { 1. Skraitas prijuostės, } \\
\text { sijono ar marškinių } \\
\text { priešakinè dalis, suim- } \\
\text { ta kam įdėti, sterblè. } \\
\text { Nuoroda Žg, o pavyz- } \\
\text { dys iš Jnš. }\end{array}$ \\
\hline sodnas & sodas & mũ.su. só·dnaz bùva (Žg) & $\begin{array}{l}\text { 1. Sodas, žemės plotas, } \\
\text { kuriame auga vaisme- } \\
\text { džiai ir vaiskrūmiai; } \\
\text { patys tame plote au- } \\
\text { gantys vaismedžiai ir } \\
\text { vaiskrūmiai. } \\
\text { Yra nuoroda Sk. }\end{array}$ \\
\hline
\end{tabular}




\begin{tabular}{|c|c|c|c|}
\hline Žodis & Reikšmè & Iliustracija & $\begin{array}{l}\text { Yra / nėra LKŽ ir } \\
\text { LKŽ(e). Reikšmè }\end{array}$ \\
\hline sodžius & kaimas & 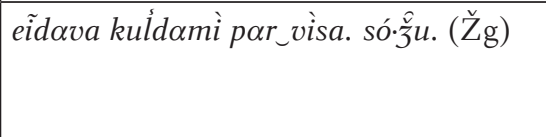 & $\begin{array}{l}\text { 1. Sodžius, kaimas. } \\
\text { Pavyzdžių nei iš Žg, } \\
\text { nei iš Jnš nėra. }\end{array}$ \\
\hline sueiga & susiejjimas & 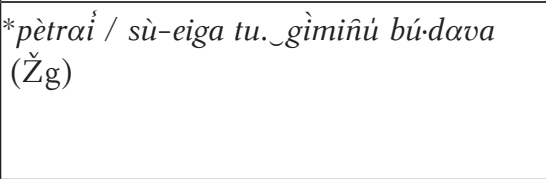 & $\begin{array}{l}\text { 1. Suejimas, susibūri- } \\
\text { mas, sambūris } \\
\text { Pavyzdžių iš Žg ar Jnš } \\
\text { nėra. }\end{array}$ \\
\hline taškas & $\begin{array}{l}\text { bet kokia } \\
\text { vieta, kur } \\
\text { galima } \\
\text { nusipirkti } \\
\text { svaigiųiu } \\
\text { gérimų }\end{array}$ & $\begin{array}{l}\text { dàbà tie_tàškaí / eĩn tie_žmõ.ni.s / gẽ.r. } \\
\text { (Daukšiai) }\end{array}$ & $\begin{array}{l}\text { Žodis yra, bet varto- } \\
\text { jamas kitomis reikš- } \\
\text { mėmis. }\end{array}$ \\
\hline trandis & skaudulys & 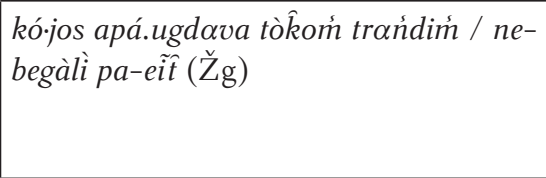 & $\begin{array}{l}\text { 6. Kojos pado, kulno } \\
\text { ar piršto tvinkinys. } \\
\text { Pavyzdžių iš Žg ar Jnš } \\
\text { nèra. }\end{array}$ \\
\hline varnuogè & mèlynè & $\begin{array}{l}\text { eidavom i_vá.rnuoĝu. nuo_*žolìnes } \\
\text { (Daukšiai) }\end{array}$ & $\begin{array}{l}\text { 5. Mèlynè. } \\
\text { Pavyzdžių iš Žg ar Jnš } \\
\text { nèra. }\end{array}$ \\
\hline
\end{tabular}

2 LENTELĖ. Žagarès šnektos būdvardžiai

\begin{tabular}{|c|c|c|c|}
\hline Žodis & Reikšmè & Iliustracija & $\begin{array}{l}\text { Yra / nèra LKŽ(e). } \\
\text { Reikšmé }\end{array}$ \\
\hline $\begin{array}{l}\text { aukštynel- } \\
\text { kas, -a }\end{array}$ & $\begin{array}{l}\text { gulintis } \\
\text { ant nuga- } \\
\text { ros }\end{array}$ & $\begin{array}{l}\text { vã.îka. paguĨdom aukštînelka. / } \\
\text { i_važúojem (Žvelgaičiai) }\end{array}$ & LKŽ nėra. \\
\hline $\begin{array}{l}\text { didysis } \\
\text { [karas }]\end{array}$ & $\begin{array}{l}\text { Pirmasis } \\
\text { pasauli- } \\
\text { nis karas } \\
1914-1918\end{array}$ & $\begin{array}{l}\text { gi.vẽ.na tòks nuo_dižeie kã.ra dã.ktors } \\
\text { / *bé.rtulis (Žagarè) }\end{array}$ & $\begin{array}{l}\text { 1. Svarbusis, žymusis. } \\
\text { Pavyzdžio iš Žagarès } \\
\text { nėra. }\end{array}$ \\
\hline gyvas, -a & $\begin{array}{l}\text { rūgstantis, } \\
\text { rūgstąs }\end{array}$ & $\begin{array}{l}\text { dèdì miẽles / ir_jìs [alus] pràded } \\
\text { gi.vé.n̂t / jau_gĩ.us añs î.r (Daukšiai) }\end{array}$ & $\begin{array}{l}\text { Iš dalies tiktų } 1 . \mathrm{Tu}- \\
\text { rintis gyvybę, bet } \\
\text { nėra nurodyta perkel- } \\
\text { tinè reikšmė. }\end{array}$ \\
\hline grynas, -a & tuščias & 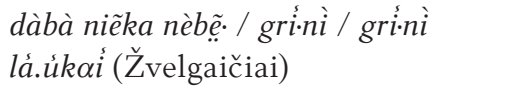 & $\begin{array}{l}\text { 10. Tuščias. } \\
\text { Pavyzdžio iš Žg nėra. }\end{array}$ \\
\hline
\end{tabular}


Fonetinès ir morfologinès Žagarès šnektos ypatybès

(XX a. pabaiga - XXI a. pradžia)

\begin{tabular}{|c|c|c|c|}
\hline Žodis & Reikšmè & Iliustracija & $\begin{array}{l}\text { Yra / nèra LKŽ(e). } \\
\text { Reikšmé }\end{array}$ \\
\hline katras & $\begin{array}{l}\text { kiekvie- } \\
\text { nas }\end{array}$ & $\begin{array}{l}\text { o_teĩp_tai kàtra. pavã.sari. tví.na } \\
\text { *daũgava }\left(\mathrm{Žg}_{\mathrm{g}}\right)\end{array}$ & $\begin{array}{l}\text { 2. Kiekvienas. } \\
\text { Pavyzdžiai iš Žg ir } \\
\text { iš Sln. }\end{array}$ \\
\hline jaukus, -i & $\begin{array}{l}\text { ramus ir } \\
\text { šiltas }\end{array}$ & 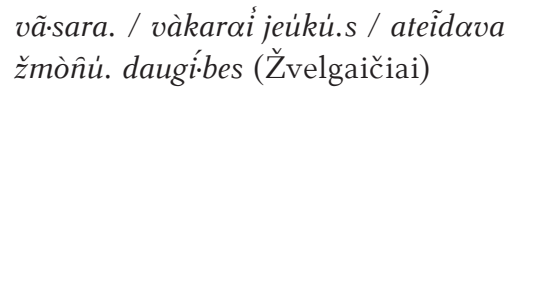 & $\begin{array}{l}\text { 3. Malonus, meilus. } \\
\text { už brūkšnio pateikti } \\
\text { pavyzdžiai rodytų } \\
\text { perkeltinę reikšmę. } \\
\text { Nėra pavyzdžių iš } \\
\text { gyvosios kalbos, tik } \\
\text { iš Daukanto raštų. }\end{array}$ \\
\hline $\begin{array}{l}\text { maktingas, } \\
\text {-a }\end{array}$ & šaunus & 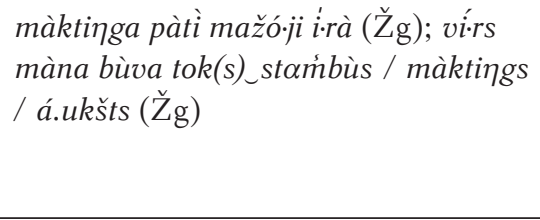 & $\begin{array}{l}\text { 2. Turintis visus rei- } \\
\text { kalingus ypatumus, } \\
\text { tinkamas, šaunus, } \\
\text { darbštus. } \\
\text { Pavyzdžių iš Žg nèra. }\end{array}$ \\
\hline mažas, -a & $\begin{array}{l}\text { turintis } \\
\text { mažai } \\
\text { žemės, } \\
\text { mažaže- } \\
\text { mis }\end{array}$ & $\begin{array}{l}\text { kàtràs mã.žaz bùva / ká. r̂ve. / á.rk̂li. } \\
\text { lã.îke [mažažemis] (Žvelgaičiai) }\end{array}$ & $\begin{array}{l}\text { Iš dalies tiktų } 6 \text {. } \\
\text { Nežymios padėties } \\
\text { visuomenèje, prastas, } \\
\text { neturtingas. } \\
\text { Pavyzdžių iš Žg nèra. }\end{array}$ \\
\hline šarpus, $-\mathrm{i}$ & darbštus & $\begin{array}{l}\text { tètè bùva šor̃pus / mú.m reĩke dí.rp̂t } \\
\text { nažiem (Žvelgaičiai) }\end{array}$ & $\begin{array}{l}1 \text { šarpus } 1 \text {. Darbštus, } \\
\text { guvus, gyvas, mitrus. } \\
\text { Pavyzdžių iš Žg ar } \\
\text { Jnš nėra. }\end{array}$ \\
\hline švakas, -a & silpnas & [sesuo] $\alpha \tilde{r}$ švàkà î. $(Z ̌ g)$ & $\begin{array}{l}\text { 1. Turintis mažai fizi- } \\
\text { nès jègos ar sveikatos. } \\
\text { Yra } 2 \text { pvz. iš Žg, bet } \\
\text { su prieveiksmiais } \\
\text { švakiau ir švakyn. }\end{array}$ \\
\hline $\begin{array}{l}\text { vienišas, -a } \\
\text { [žodis] }\end{array}$ & $\begin{array}{l}\text { paauglių } \\
\text { keiksmai } \\
\text { ir kalba } \\
\text { su keiks- } \\
\text { mažo- } \\
\text { džiais }\end{array}$ & $\begin{array}{l}\text { isitrá.uke cigarètès / blèd blèd / vieniši } \\
\text { tòkiè žõŏ̌ei (Žvelgaičiai) }\end{array}$ & $\begin{array}{l}2 \text { vienišas } 1 . / / \text { neį- } \\
\text { einantis ị daugianarę } \\
\text { sistemą. } \\
\text { Pavyzdžių iš gyvo- } \\
\text { sios kalbos nėra, iš } \\
\text { raštų yra. }\end{array}$ \\
\hline vijinis & $\begin{array}{l}\text { liktarnos } \\
\text { rūšis }\end{array}$ & tòkes liktá.rnaz bú.dava / viiìnes (Žg) & LKŽ nėra. \\
\hline
\end{tabular}


3 LENTELĖ. Žagarès šnektos veiksmažodžiai ir jų formos (dalyviai, prieveiksmiai)

\begin{tabular}{|c|c|c|c|}
\hline Žodis & Reikšmè & Iliustracija & $\begin{array}{l}\text { Yra / nèra LKŽ(e). } \\
\text { Reikšmé }\end{array}$ \\
\hline atgaliau & atgal & jiñ grĩ.ža tàd(à) àdgalæú (Žiuriaĩ) & LKŽ nėra. \\
\hline bliauti & $\begin{array}{l}\text { atsikalbi- } \\
\text { nèti } \\
\text { garsiai } \\
\text { šaukiant } \\
\text { kviesti }\end{array}$ & 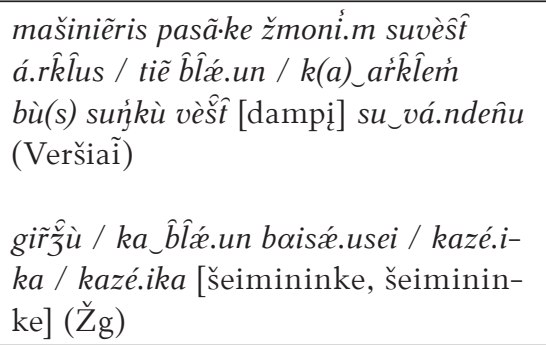 & $\begin{array}{l}\text { Žodis LKŽ yra, bet } \\
\text { nėra pavyzdžių iš Žg } \\
\text { ar Jnš tokiomis reikš- } \\
\text { mėmis. }\end{array}$ \\
\hline eiti & $\begin{array}{l}\text { tęstis, } \\
\text { trukti }\end{array}$ & 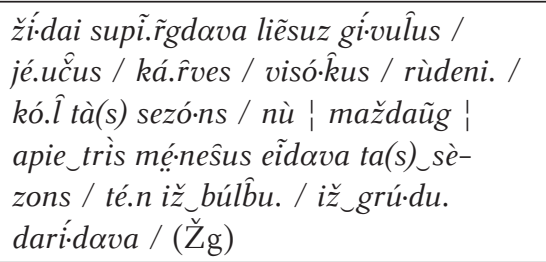 & $\begin{array}{l}\text { 4. Slinkti (apie laiką). } \\
\text { Pavyzdžių iš Žg nèra. }\end{array}$ \\
\hline išbraižyti & $\begin{array}{l}\text { išskutinè- } \\
\text { ti peiliu- } \\
\text { ku (mar- } \\
\text { gučius) }\end{array}$ & $\begin{array}{l}\text { kìcs mokẹ.dava [kiaušinius] ižbrá.iži.t.t } \\
(\grave{Z} g)\end{array}$ & $\begin{array}{l}\text { Iš dalies tiktǔ } 3 \text {. Iš- } \\
\text { piešti, išbrèžti. } \\
\text { Pavyzdžių iš Žg nèra. }\end{array}$ \\
\hline išsiblaivèti & $\begin{array}{l}\text { nukristi } \\
\text { putoms }\end{array}$ & $\begin{array}{l}\text { isibloivẹ́:i tos_pùtas / nebẹ:ra jũ. [apie } \\
\text { alaus darymą] (Veršiaĩ) }\end{array}$ & $\begin{array}{l}\text { Žodis yra kitomis } \\
\text { reikšmėmis. }\end{array}$ \\
\hline išvartoti & $\begin{array}{l}\text { išleisti už } \\
\text { vyro }\end{array}$ & 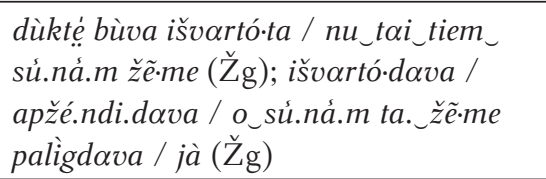 & $\begin{array}{l}\text { Išleisti už vyro. } \\
\text { Pavyzdys iš Sk. }\end{array}$ \\
\hline juodai & $\begin{array}{l}\text { atsidavu- } \\
\text { siai }\end{array}$ & 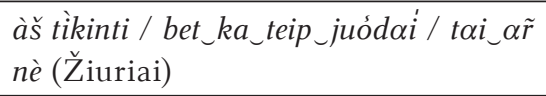 & $\begin{array}{l}\text { Žodis yra, bet nèra } \\
\text { tokios reikšmės. }\end{array}$ \\
\hline kvarksèti & šnekèti & 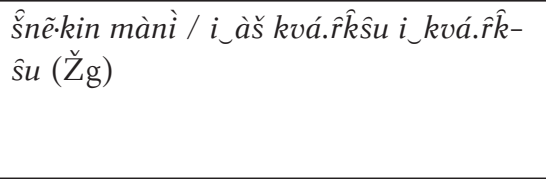 & $\begin{array}{l}\text { Iš dalies tiktų 3. Prk. } \\
\text { murmėti, bambėti; } \\
\text { piktai, stačiai kalbėti. } \\
\text { Pavyzdžio iš Žg nèra. }\end{array}$ \\
\hline laisvai & $\begin{array}{l}\text { neap- } \\
\text { gaubtai } \\
\text { (stiklu) }\end{array}$ & 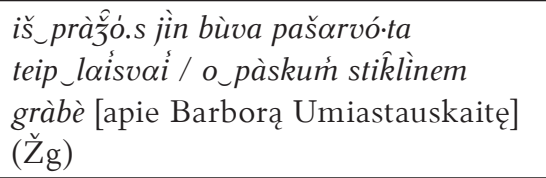 & $\begin{array}{l}\text { Žodis yra, bet kito- } \\
\text { mis reikšmėmis. }\end{array}$ \\
\hline
\end{tabular}


Fonetinès ir morfologinès Žagarès šnektos ypatybès

(XX a. pabaiga - XXI a. pradžia)

\begin{tabular}{|c|c|c|c|}
\hline Žodis & Reikšmè & Iliustracija & $\begin{array}{l}\text { Yra / nèra LKŽ(e). } \\
\text { Reikšmé }\end{array}$ \\
\hline minkyti & $\begin{array}{l}\text { ritmiškai } \\
\text { kelti ko- } \\
\text { jas }\end{array}$ & $\begin{array}{l}\text { àš teîib gràžei á.ušče / kó.jes mí.nki.če } \\
\text { (Žiuriaĩ) }\end{array}$ & $\begin{array}{l}\text { Iš dalies tiktų 1. prk. } \\
\text { mindyti. } \\
\text { Pavyzdžių iš Žg ar } \\
\text { Jnš nèra. }\end{array}$ \\
\hline $\begin{array}{l}\text { nudilęs, } \\
\text {-usi }\end{array}$ & $\begin{array}{l}\text { nebeprisi- } \\
\text { menamas }\end{array}$ & 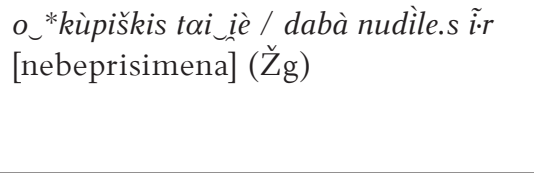 & $\begin{array}{l}\text { 2. Pranykti, pradingti, } \\
\text { prapulti; Yra nuoroda } \\
\text { prk. } \\
\text { Pavyzdžių iš Žg nèra. }\end{array}$ \\
\hline nusitverti & $\begin{array}{l}\text { kartu gy- } \\
\text { venti }\end{array}$ & $\begin{array}{l}\text { čè_jeu nebe_pirmó:ii / kita. mótteriška. } \\
\text { tùrù nusî́tvệre.s / jà (Veršiaĩ) }\end{array}$ & $\begin{array}{l}\text { Iš dalies tiktų } \\
\text { 2. Tverti. 2. Kibtis, } \\
\text { kabintis, norint išsi- } \\
\text { laikyti ar sulaikyti. } \\
\text { Pavyzdžių iš Žg ar } \\
\text { Jnš nėra. }\end{array}$ \\
\hline nuūžti & $\begin{array}{l}\text { skubiai } \\
\text { nueiti }\end{array}$ & mã.s / vìsà kệ.bra nù-u.žæm (Žg) & $\begin{array}{l}\text { 8. Greitai kur nuvyk- } \\
\text { ti, nubėgti. } \\
\text { Pavyzdžių iš Žg ar } \\
\text { Jnš nėra. }\end{array}$ \\
\hline plačiai & $\begin{array}{l}\text { išsiskirs- } \\
\text { čius po } \\
\text { pasaulị ir } \\
\text { Lietuvą } \\
\text { turtin- } \\
\text { giau }\end{array}$ & plàčeú žmó.ní.s gi.vé.n (Žiuriai) & $\begin{array}{l}\text { Iš dalies tiktų } 2 . \text { I } \\
\text { visas puses nusitęsęs. } \\
\text { 9. Nesaikingas, iš- } \\
\text { laidus. } \\
\text { Pavyzdžiu iš Žg ar } \\
\text { Jnš nėra. }\end{array}$ \\
\hline $\begin{array}{l}\text { praprusęs, } \\
\text {-usi }\end{array}$ & $\begin{array}{l}\text { pasimo- } \\
\text { kęs }\end{array}$ & $\begin{array}{l}\text { kur̃ praprùse. / tai_dãa.kaip_nórs ver̃- } \\
\text { čes (Žiuriai) }\end{array}$ & $\begin{array}{l}\text { 1. Praprusti } 1 \text {. Išprus- } \\
\text { ti, prasilavinti. } \\
\text { Pavyzdžių iš Žg nèra. }\end{array}$ \\
\hline prastai & silpnai & 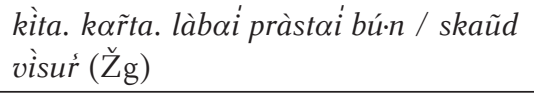 & $\begin{array}{l}\text { 6. Silpnas, nestiprus. } \\
\text { Pavyzdžių iš Žg nėra. }\end{array}$ \\
\hline prietariškai & $\begin{array}{l}\text { tikint } \\
\text { burtais }\end{array}$ & $\begin{array}{l}\text { priẽtariškai nè / nè / nebú.dava [bur- } \\
\text { tais netikèjo] (Žiuriaĩ) }\end{array}$ & LKŽ nėra. \\
\hline
\end{tabular}




\begin{tabular}{|c|c|c|c|}
\hline Žodis & Reikšmė & Iliustracija & $\begin{array}{l}\text { Yra / nèra LKŽ(e). } \\
\text { Reikšmé }\end{array}$ \\
\hline parsikviesti & $\begin{array}{l}\text { ikalbèti } \\
\text { sugrịžti, } \\
\text { parsi- } \\
\text { vadinti } \\
\text { gyventi }\end{array}$ & $\begin{array}{l}\text { jiñ turẹ́:ie namẽ.li. / mùm parsìikviete } \\
\text { (Veršiaĩ) }\end{array}$ & $\begin{array}{l}\text { Paprašyti, pavadinti, } \\
\text { pašaukti ką kur at- } \\
\text { vykti, dalyvauti. } \\
\text { Nėra pavyzdžiu iš } \\
\text { gyvosios kalbos, tik } \\
\text { iš raštų. }\end{array}$ \\
\hline ropa & ropomis & 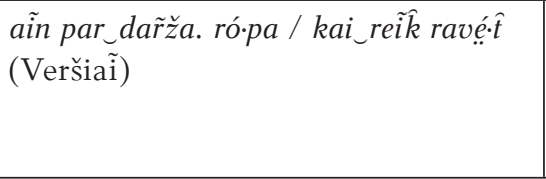 & $\begin{array}{l}\text { 3. Ropa, ropomis, ke- } \\
\text { turpėsčias. } \\
\text { Yra du pavyzdžiai iš } \\
\text { Jnš. }\end{array}$ \\
\hline skaudžiai & šiurkščiai & 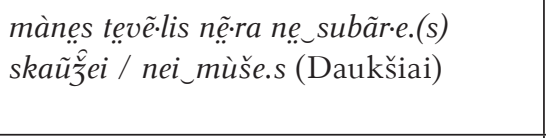 & $\begin{array}{l}\text { 4. Šiurkštus, } \\
\text { ị̌židžiantis, užgaulus. } \\
\text { Pavyzdžiu iš Žg nėra. }\end{array}$ \\
\hline spardytis & $\begin{array}{l}\text { praban- } \\
\text { giai gy- } \\
\text { venti }\end{array}$ & 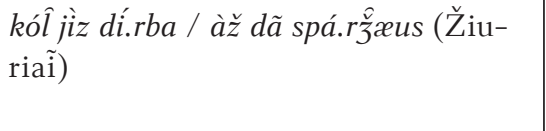 & $\begin{array}{l}\text { Žodis LKŽ yra, bet } \\
\text { ne tokia reikšme. }\end{array}$ \\
\hline stoksoti & $\begin{array}{l}\text { būti } \\
\text { nereika- } \\
\text { lingam, } \\
\text { stovèti }\end{array}$ & 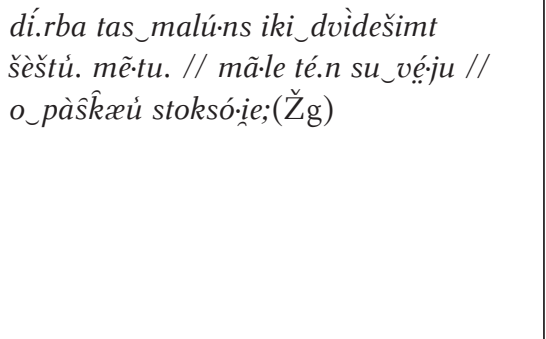 & $\begin{array}{l}\text { Artimiausia žodžio } \\
\text { stūksoti reikšmė } 1 . \\
\text { Būti, stovėti iškilu- } \\
\text { siam iš aplinkos. Tik } \\
\text { čia ne tokia reikšmė. } \\
\text { Žodis stoksoti LKŽ } \\
\text { yra, bet pavyzdžiai } \\
\text { tik iš raštų. }\end{array}$ \\
\hline sulygti & suderèti & 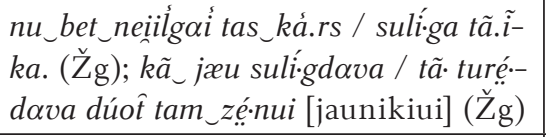 & $\begin{array}{l}\text { 1 Sulygti } 1 . \text { Suderèti. } \\
\text { Pavyzdžiǔ iš Žg ar } \\
\text { Jnš nèra. }\end{array}$ \\
\hline susitverti & gimti & 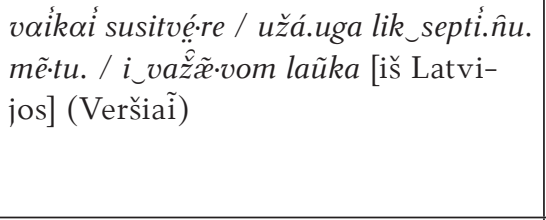 & $\begin{array}{l}\text { Iš dalies tiktų } 10 . \\
\text { Padaryti, kad būtų, } \\
\text { egzistuotų. } \\
\text { Pavyzdžių iš Žg ar } \\
\text { Jnš nėra. }\end{array}$ \\
\hline $\begin{array}{l}\text { sušiauštas, } \\
\text {-a }\end{array}$ & $\begin{array}{l}\text { nelygaus } \\
\text { paviršiaus }\end{array}$ & $\begin{array}{l}\text { tõ. pùsẹ. *ventà / lèdú. sùšxšta (Ver- } \\
\text { šia î) }\end{array}$ & $\begin{array}{l}\text { 1. // padaryti nelygų, } \\
\text { neglotną, pašiurusį. } \\
\text { Pavyzdžių iš Žg nèra. }\end{array}$ \\
\hline šaukti & vadinti & 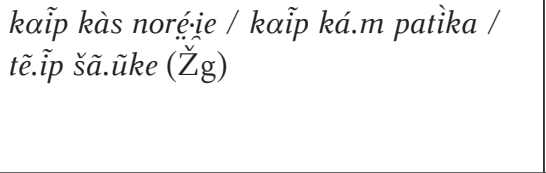 & $\begin{array}{l}\text { 16. Vadinti (vardu, } \\
\text { pavadinimu, pravar- } \\
\text { de). Pavyzdžių iš Žg } \\
\text { ar Jnš nėra. }\end{array}$ \\
\hline
\end{tabular}


Fonetinès ir morfologinès Žagarès šnektos ypatybès

(XX a. pabaiga - XXI a. pradžia)

\begin{tabular}{|c|c|c|c|}
\hline Žodis & Reikšmè & Iliustracija & $\begin{array}{l}\text { Yra / nėra LKŽ(e). } \\
\text { Reikšmė }\end{array}$ \\
\hline tikybiškai & religiškai & bùvom tikíbiškai á.uklẹjami (Žiuriaĩ) & $\begin{array}{l}\text { Būdingas tikybai, re- } \\
\text { ligiškas. Pavyzdžių iš } \\
\text { Žg ar Jnš nėra. }\end{array}$ \\
\hline valioj & $\begin{array}{l}\text { pravirai, } \\
\text { atidary- } \\
\text { tos }\end{array}$ & išeinù / vìsoz dùri.s vã.loị (Žg) & $\begin{array}{l}\text { Apie ką atvertą, atvi- } \\
\text { rą, atdarą (ppr. apie } \\
\text { duris, langus, vartus). } \\
\text { Pavyzdys iš Jnš, o iš } \\
\text { Žg nėra. }\end{array}$ \\
\hline važiuoti & $\begin{array}{l}\text { būti pa- } \\
\text { šautam ì } \\
\text { duonkepę } \\
\text { krosnị }\end{array}$ & 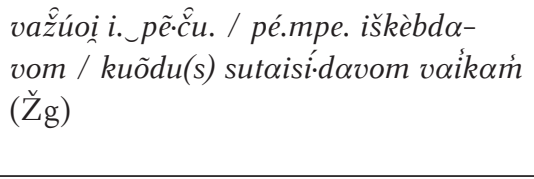 & $\begin{array}{l}\text { Iš dalies tiktų } 21 . \\
\text { Slinkti, slysti. } \\
\text { Pavyzdžių iš Žg ar } \\
\text { Jnš nèra }\end{array}$ \\
\hline viršuj & $\begin{array}{l}\text { sudeda- } \\
\text { masis } \\
\text { perfici- } \\
\text { entyvo } \\
\text { dèmuo }\end{array}$ & šùnis užlé.izdava viřšui (Žiuriaĩ) & LKŽ yra žodis viršuje. \\
\hline
\end{tabular}

4 LENTELĖ. Žagarès šnektos nesavarankiškos kalbos dalys

\begin{tabular}{|c|c|c|c|}
\hline Žodis & Reikšmè & Iliustracija & $\begin{array}{l}\text { Yra / nėra LKŽ(e). } \\
\text { Reikšmé }\end{array}$ \\
\hline ar & taip pat & 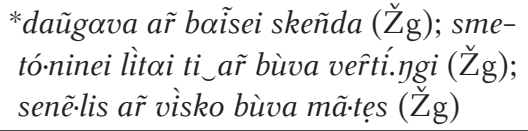 & $\begin{array}{l}\text { 3. Ar taip pat, irgi, ir. } \\
\text { Pavyzdžių iš Žg ar } \\
\text { Jnš nėra. }\end{array}$ \\
\hline dui & $\begin{array}{l}\text { bègimui } \\
\text { nusakyti }\end{array}$ & 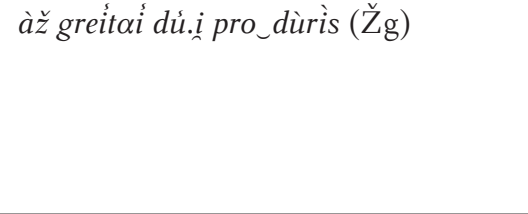 & $\begin{array}{l}\text { Skubiam veiksmui, } \\
\text { ppr. bėgimui, nusa- } \\
\text { kyti. } \\
\text { Pavyzdžių iš Žg ar } \\
\text { Jnš nėra. }\end{array}$ \\
\hline džing & $\begin{array}{l}\text { skeidžia- } \\
\text { mam } \\
\text { garsui } \\
\text { imituoti }\end{array}$ & 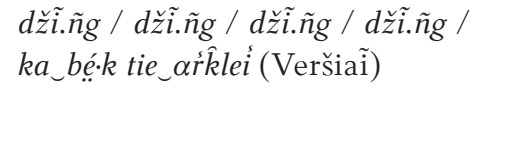 & LKŽ nėra. \\
\hline
\end{tabular}




\begin{tabular}{|c|c|c|c|}
\hline Žodis & Reikšmė & Iliustracija & $\begin{array}{l}\text { Yra / nèra LKŽ(e). } \\
\text { Reikšmé }\end{array}$ \\
\hline gan & $\begin{array}{l}\text { daug, pa- } \\
\text { kankamai }\end{array}$ & $\begin{array}{l}\text { víenu mó.mentu gañ bùva / pí.r̂mi- } \\
\text { ningz bùva nev.êede.s / agrònoms ne- } \\
\text { vẽ.des / píenininks (Žg) }\end{array}$ & $\begin{array}{l}\text { 1. Pakanka, užtenka } \\
\text { pakankamai, užtek- } \\
\text { tinai. } \\
\text { LKŽ yra žodis gana, } \\
\text { bet pavyzdžių iš Žg } \\
\text { nėra. }\end{array}$ \\
\hline makt & kyšt & 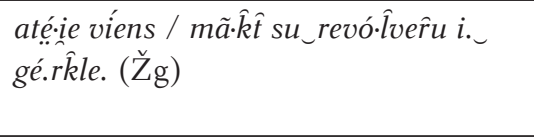 & $\begin{array}{l}\text { 1. Staigiam veiksmui } \\
\text { žymèti c) kyšt, durst. } \\
\text { Pavyzdys iš Žg. }\end{array}$ \\
\hline musėnt & $\begin{array}{l}\text { turbūt, } \\
\text { gal }\end{array}$ & $\begin{array}{l}\text { mùsẹ.nt jeu_dàbà bùs ta_tìkrà *liétuvà } \\
\left(\mathrm{Žg}_{\mathrm{g}}\right)\end{array}$ & $\begin{array}{l}\text { Icterptinis žodis. } \\
\text { Pavyzdžiu iš Žg ar } \\
\text { Jnš nèra. }\end{array}$ \\
\hline musint & gal & $\begin{array}{l}\text { mùsint toz_gegužinẹs tó } \cdot \hat{k} o s \text { ir_írà } \\
(\text { Žg })\end{array}$ & $\begin{array}{l}\text { İterptinis žodis. } \\
\text { Pavyzdžiu iš Žg ar } \\
\text { Jnš nėra. }\end{array}$ \\
\hline nèmaž & visai & 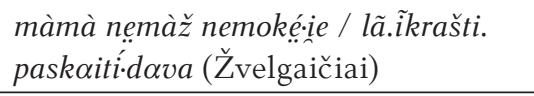 & $\begin{array}{l}\text { Nè kiek, visai. } \\
\text { Pavyzdys iš Žg. }\end{array}$ \\
\hline pliumpt & $\begin{array}{l}\text { kritimui } \\
\text { í vandenị } \\
\text { nusakyti }\end{array}$ & 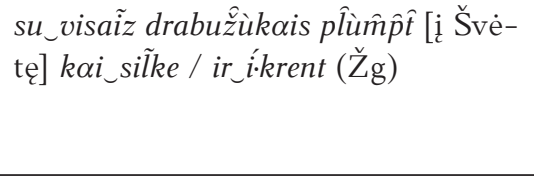 & $\begin{array}{l}\text { Kritimui į vandenị } \\
\text { reikšti. } \\
\text { Pavyzdžių iš Žg ar } \\
\text { Jnš nėra. }\end{array}$ \\
\hline pur & $\begin{array}{l}\text { burzgimui } \\
\text { imituoti }\end{array}$ & $\begin{array}{l}\text { iš_tólla ižgir̃sim / ka_pur̃ pur̃ pur̃ / } \\
\text { mó.ki.tojes kaškòks turẹ́:ie mọtòcikla. } \\
(\text { Žg) }\end{array}$ & $\begin{array}{l}\text { 3. Burzgimui žymėti. } \\
\text { Pavyzdžių iš Žg ar } \\
\text { Jnš nèra. }\end{array}$ \\
\hline
\end{tabular}

\section{Phonetic and Morphological Peculiarities of Žagare Local Dialect (End of the 20 $0^{\text {th }}$ Century - Beginning of the $21^{\text {st }}$ Century)}

\section{SUMMARY}

In this article the author presents the continued research on Žagare local dialect. This time the article is dedicated to the accentual, phonetic, morphological phenomena found in Žagare local dialect and its peculiar lexical characteristics. According to the author, the accentual tendencies and dialectal grammatical phenomena apparent in the records of Žagare 
Fonetinès ir morfologinès Žagarès šnektos ypatybès

(XX a. pabaiga - XXI a. pradžia)

local dialect made between 1998 and 2003 lead to the works of the $21^{\text {st }}$ century - the study on the change of the dialect.

Dialectologists attribute Žagare local dialect to the area of universal stress retraction. The peculiarities of accentuation of mixed diphthongs observed by linguists Juozas Pabrèža and Aušra Kaikaryte deserve a more detailed study and correction with regard to the informant's national belonging and linguistic identity. Certain phonetic peculiarities, such as the pronunciation of vowels $a, e, i, u$ and consonants $c h, f, h$, the use of additive $j$, v, the so called phenomenon of šlekiavimas and the softening/ hardening of consonants, reflect the dialect's phonetic system. They can still be found in the dialectal records of the late $20^{\text {th }}$ century.

The morphological peculiarities of Žagare local dialect, such as stem alteration in nominal words, number and gender variations, use of the dual number, peculiar (or borrowed from close local dialects) formation of nominal word forms (pronominal, degree, reflexive), as well as the peculiarities of the usage of verb stems and forms are still viable and satisfy the respondents' needs for linguistic expression.

Dialectal records enable us to understand how words are formed in Žagarẻ local dialect. The respondents mainly used suffixal and prefixal derivatives and compounds. Noun derivatives were formed with suffixes -atis, -ejjas, -elis, -ietis, -tojas, -uitis, whereas -ingas, -inis, -utis were more common adjectival suffixes. Prefixal verb formation with prefixes ap-, nu-, pa-, par-, pri- took the lead. The speakers of Žagare local dialect used to form compounds without a connecting vowel.

The review of the lexical cross-section of Žagare local dialect provides us with an insight into the peculiar lexis used in the dialect. The word or its form subtly selected by the respondents to describe images or phenomena shows the flexibility of the mother tongue and its suitability to express thoughts under contemporary conditions.

Itteikta 2019 m. gegužès 17 d.

JANINA ŠVAMBARYTE்-VALUŽIENE்

Lietuviu kalbos institutas

Petro Vilešio g. 5, LT- 10308 Vilnius, Lietuva

janina.valuziene@gmail.com 